Article

\title{
Hybridisation Potential of 1',3'-Di-O-methylaltropyranoside Nucleic Acids
}

\author{
Akkaladevi Venkatesham ${ }^{\dagger}$, Dhuldeo Kachare ${ }^{\dagger}$, Guy Schepers, Jef Rozenski, Mathy Froeyen \\ and Arthur Van Aerschot*
}

Medicinal Chemistry, Rega Institute for Medical Research, KU Leuven, Minderbroedersstraat 10, Leuven BE-3000, Belgium; E-Mails: akkaladevi.venkatesham@rega.kuleuven.be (A.V.); ddkachare@gmail.com (D.K.); Guy.Schepers@rega.kuleuven.be (G.S.);

Jef.Rozenski@rega.kuleuven.be (J.R.); Mathy.Froeyen@rega.kuleuven.be (M.F.);

$\dagger$ These authors contributed equally to this work.

* Author to whom correspondence should be addressed;

E-Mail: Arthur.Vanaerschot@rega.kuleuven.be; Tel.: +32-16-372-624.

Academic Editor: Mahesh K. Lakshman

Received: 22 January 2015 / Accepted: 24 February 2015 / Published: 3 March 2015

\begin{abstract}
In further study of our series of six-membered ring-containing nucleic acids, different 1',3'-di-O-methyl altropyranoside nucleoside analogs (DMANA) were synthesized comprising all four base moieties, adenine, cytosine, uracil and guanine. Following assembly into oligonucleotides (ONs), their affinity for natural oligonucleotides was evaluated by thermal denaturation of the respective duplexes. Data were compared with results obtained previously for both anhydrohexitol (HNAs) and 3'-O-methylated altrohexitol modified ONs (MANAs). We hereby demonstrate that ONs modified with DMANA monomers, unlike some of our previously described analogues with constrained 6-membered hexitol rings, did not improve thermodynamic stability of dsRNA complexes, most probably in view of an energetic penalty when forced in the required $1 \mathrm{C} 4$ pairing conformation. Overall, a single incorporation was more or less tolerated or even positive for the adenine congener, but incorporation of a second modification afforded a slight destabilization (except for A), while a fully modified sequence displayed a thermal stability of $-0.3{ }^{\circ} \mathrm{C}$ per modification. The selectivity of pairing remained very high, and the new modification upon incorporation into a DNA strand, strongly destabilized the corresponding DNA duplexes. Unfortunately, this new modification does not bring any advantage to be further evaluated for antisense or siRNA applications.
\end{abstract}


Keywords: modified oligonucleotides; hexitol nucleic acids; pairing behaviour; hybridisation; constrained oligonucleotides

\section{Introduction}

Gene silencing has become a standard technique for studying gene functions or in trying to obtain therapeutic effects and theoretically can be attained by interfering with transcription (via formation of triple stranded complexes [1] or translation processes. The latter can be obtained via steric blocking antisense oligonucleotides (ASOs) or via mRNA cleavage of double stranded complexes with RNAseH activating ASOs [2-4]. However, the vast majority of researchers nowadays have turned to the use of RNA interference (RNAi)-based strategies, which has recently become the technique of choice to silence gene expression in mammalian cell culture and is envisaged as a first choice for therapeutic treatment as well [5-7]. However, we need to point out that at the moment only one aptamer [8] and one antisense oligonucleotide have been effectively FDA approved for gene silencing [9], and also exon-skipping oligonucleotides are receiving considerable attention [10].

In cell culture in general unmodified siRNAs are highly efficient, however for in vivo application some chemical modifications are warranted to stabilise the siRNAs and to increase their selectivity and to promote delivery $[11,12]$. In the past, we and others have studied a wide variety of strategies for both ASO and siRNA modification as reviewed several times [13-15].

Our group has been very successful in increasing the affinity for RNA using modified building blocks based on 6-membered hexitol rings which resulted in the hexitol nucleic acids series [16-19]. However, the LNA monomers of the Wengel group [20] consistently showed the strongest affinity for RNA, and the series comprises many alternative structures [21]. Overall, both our hexitol nucleic acids and the LNA series of compounds take on a pre-organized conformation, fitting the A-form of dsRNA and rationalizing the strong hybridization characteristics noticed.

Herein, hexitol nucleic acids (HNA, Figure 1) are composed of 2,3-dideoxy-D-arabino-hexitol units with a nucleobase situated in the 2-(S)-position (in cis to the hydroxymethyl substituent as in natural nucleosides). Addition of a supplementary hydroxyl at the 3'- $\alpha$-position resulted in D-altritol nucleic acid (ANA, Figure 1) analogs with increased affinity for RNA strands [18,22]. More recently, we finally reported on the 3'-O-methylated ANA congeners (MANA, Figure 1) resulting in a further increase of $0.5^{\circ} \mathrm{C} /$ modification when evaluating melting temperatures $\left(\mathrm{T}_{\mathrm{m}}\right)$ upon hybridisation to RNA [23]. Herein, both the heterocyclic base and the $3^{\prime}$ - $O$-methyl moiety are located in an axial position with a ${ }^{4} \mathrm{C}_{1}$ conformation. However, assembly of the hexitol series of nucleosides is long-routed starting with synthesis of the 1,5-anhydrohexitol ring. In view of the positive results obtained for the MANA series of congeners and the abundance of cheap $\alpha$-D-methylglucoside, we now planned to prepare and evaluate "bis-methylated altritol nucleosides", or more correctly di- $O$-methylated altropyranoside nucleic acids (DMANA, Figure 1). 


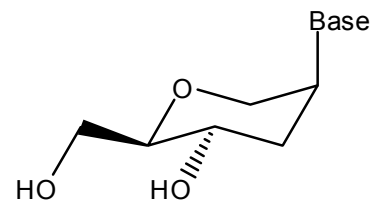

HNA

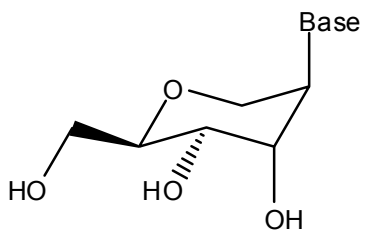

ANA

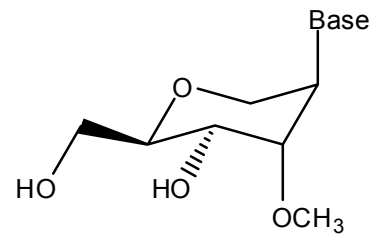

MANA

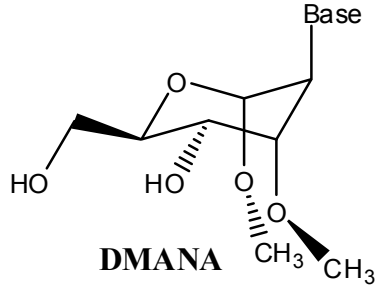

Figure 1. Structures of the different hexitol based nucleic acids (HNA, ANA and MANA) as discussed above and the newly envisaged structure DMANA, based on methyl-altropyranoside.

\section{Results and Discussion}

\subsection{Chemical Synthesis of the New Building Blocks}

The 1'- $O$-methylglycosidic protected analogues 4, 6 and 9 (Scheme 1) were obtained starting from ubiquitous methyl glucopyranoside $\mathbf{1}$, which in three steps was converted to $\mathbf{2}$ in $51.4 \%$ overall yield according to literature procedures [24]. Herein, regioselective epoxide ring opening of $\mathbf{2}$ with the sodium salts of uracil or adenine in DMF at $120-130{ }^{\circ} \mathrm{C}$ afforded the corresponding altrohexitol derivatives 3 and 7 in 66\%-85\% yield. Chemoselective methylation of 7 and 3 was accomplished using $\mathrm{NaH}, \mathrm{MeI}$ in dry THF at low temperature for $1 \mathrm{~h}$ to afford the methylated nucleosides $\mathbf{4}$ and 8 in $65 \%$ and $75 \%$ yield, respectively. The selective $O-v s$. $N$-methylation mainly depends upon the dielectric constant of the solvent [23,25] and the stability of sodium-enolate chelation [26]. Hence, low dielectric constant and high chelation stabilizing capacity of THF afforded a higher $O$-selectivity compared to DMF. The one pot conversion of compound 3 to the triazolide derivative [27] using 1,2,4-triazole, $\mathrm{POCl}_{3}$, and triethylamine, and subsequent treatment with aqueous ammonia/dioxane (1:1) at ambient temperature for $18 \mathrm{~h}$ yielded the cytidine derivative (5) with 58\% (overall yield for 2 steps). Base protection of 5 and 8 using benzoylchloride in pyridine at $\mathrm{rt}$ for $3 \mathrm{~h}$ afforded $\mathbf{6}$ and $\mathbf{9}$ in 83 and $88 \%$ yield, respectively.

Due to the scalability, solubility and reproducibility of the reaction it proved advantageous to use the guanine derivative $\mathbf{1 0}$ for the epoxide ring opening reaction. The latter was obtained via Mitsunobu reaction of $N^{2}$-acetylguanine [28] and 2-(trimethylsilyl)ethanol in analogy with the previously described protocol for $O^{6}$-[2-( $p$-nitrophenyl)ethyl]guanine [29]. Selective epoxide ring opening was accomplished with the lithium salt of $\mathbf{1 0}$ (Scheme 2) in DMF at $130{ }^{\circ} \mathrm{C}$ and afforded $41 \%$ of $\mathbf{1 1}$ along with $26 \%$ of recovered 10. Remarkably, the acetyl protection was lost in 11 upon the prolonged heating in DMF. Further chemoselective methylation using $\mathrm{NaH}(60 \%)$ and $\mathrm{MeI}$ in DMF and DCM at low temperature for $4 \mathrm{~h}$ gave 12 in 94\% yield. Deprotection of 12 was done by $1 \mathrm{M}$ TBAF in THF at $\mathrm{rt}$ for $2 \mathrm{~h}$ to yield $75 \%$ of 13 . The more base labile $N^{2}$-dimethylformamidine ( $\mathrm{dmf}$ ) [30-32] group was introduced using $\mathrm{N}, \mathrm{N}$-dimethylformamide diethylacetal in methanol under reflux for $12 \mathrm{~h}$ to afford $\mathbf{1 4}$ with $85 \%$ yield. 

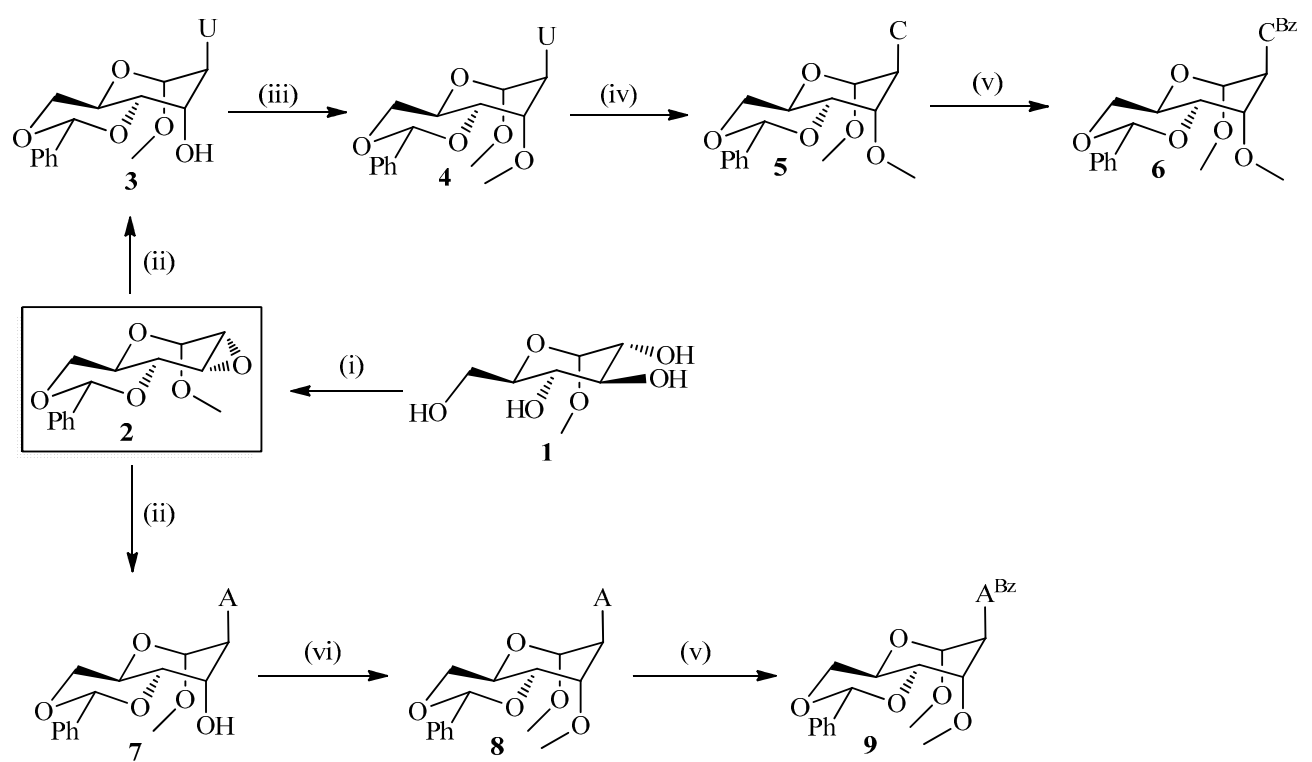

Reagents and Conditions: (i) (a) $\mathrm{C}_{6} \mathrm{H}_{5} \mathrm{CHO}, \mathrm{ZnCl}_{2}, 72 \mathrm{~h}\left(66 \%\right.$ ); (b) 6 eq. $\mathrm{CH}_{3} \mathrm{C}_{6} \mathrm{H}_{4} \mathrm{SO}_{2} \mathrm{Cl}$, pyridine, $60{ }^{\circ} \mathrm{C}$, $72 \mathrm{~h}$ (78\%); (c) $5.3 \mathrm{M}$ in $\mathrm{MeOH}, \mathrm{CH}_{2} \mathrm{Cl}_{2}$, rt, $12 \mathrm{~h}$ (99\%); (ii) $\mathrm{NaH}(60 \%)$, DMF, $20^{\circ} \mathrm{C}, 12 \mathrm{~h}$ (33.3\% of 3 along with $40.1 \%$ recovery of 2 and $75 \%$ of 7); (iii) $\mathrm{NaH}(60 \%), \mathrm{CH}_{3} \mathrm{I}, \mathrm{THF}, 0{ }^{\circ} \mathrm{C}, 1 \mathrm{~h}(64.7 \%)$; (iv) (a) $\mathrm{POCl}_{3}$, $1 H$-1,2,4-triazole, Et ${ }_{3} \mathrm{~N}$, pyridine, rt, $2 \mathrm{~h}$; (b) 1,4 dioxane, aq. $\mathrm{NH}_{3}, \mathrm{rt}, 12 \mathrm{~h}$ ( $58.17 \%$ overall 2 steps); (v) Benzoyl chloride, pyridine, rt, $3 \mathrm{~h}\left(87.6 \%\right.$ of $\mathbf{6}$ and $83 \%$ of $\mathbf{9}$; (vi) $\mathrm{NaH}(60 \%), \mathrm{CH}_{3} \mathrm{I}, \mathrm{THF},-78{ }^{\circ} \mathrm{C}, 4.5 \mathrm{~h}$ to $-30{ }^{\circ} \mathrm{C}$, $1 \mathrm{~h}(75 \%)$.

Scheme 1. Synthetic scheme of the protected DMANA congeners for uracil, cytosine and adenine.

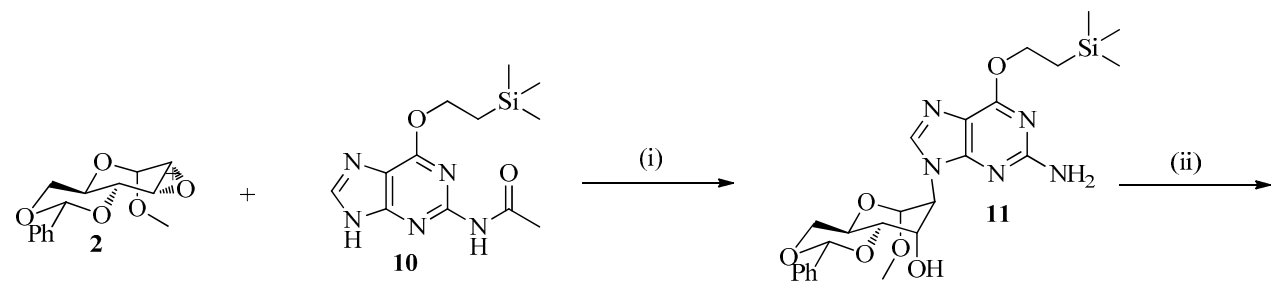

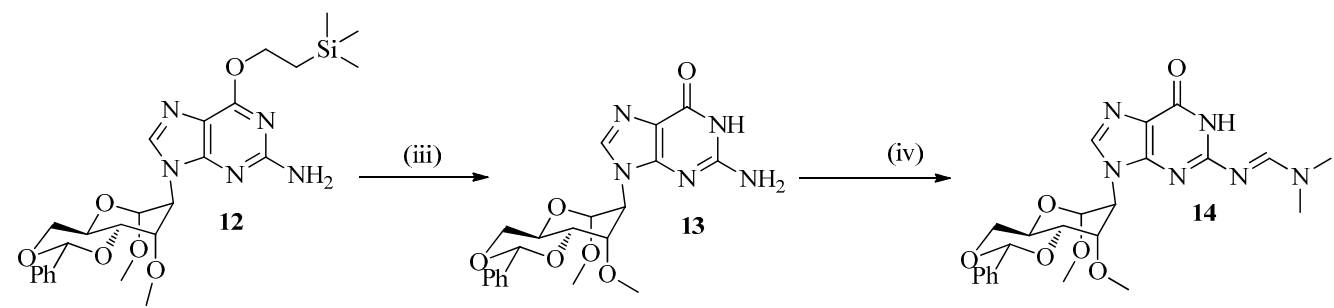

Reagents and Conditions: (i) LiH, DMF, $130{ }^{\circ} \mathrm{C}, 18 \mathrm{~h}$ (42\% of $\mathbf{1 1}$ along with $26 \%$ recovery of 10); (ii) $\mathrm{NaH}$ (60\%), $\mathrm{CH}_{3} \mathrm{I}$, DMF, DCM, $-30{ }^{\circ} \mathrm{C}$ to $-20{ }^{\circ} \mathrm{C}, 4 \mathrm{~h}$ (94\%); (iii) TBAF, THF, rt, $2 \mathrm{~h}(75 \%)$; (iv) $\mathrm{Me}_{2} \mathrm{NCH}(\mathrm{OEt})_{2}$, $\mathrm{MeOH}$, reflux for $12 \mathrm{~h}(85 \%)$.

Scheme 2. Synthetic scheme for the protected guanine containing analog.

Deprotection of the benzylidene protecting group under mild conditions using $\mathrm{AcOH}: \mathrm{H}_{2} \mathrm{O}(3: 1)$ at $45{ }^{\circ} \mathrm{C}$ for $12 \mathrm{~h}$ afforded 15a-d in 50\%-94\% yield (Scheme 3), which was followed by classical dimethoxytritylation and phosphitylation. Hereto, the nucleosides $\mathbf{1 5 a}-\mathbf{d}$ were selectively protected at the 6 '-OH by reaction with $\mathrm{DMTrCl}$ in pyridine at $\mathrm{rt}$ for $3 \mathrm{~h}$ to furnish the corresponding protected derivatives 16a-d in 74\%-93\% yield. Phosphitylation of 16a-d at the 4'-OH with 2-cyanoethyl $N, N$-diisopropylchlorophosphoramidite in anhydrous $\mathrm{CH}_{2} \mathrm{Cl}_{2}$ at $0{ }^{\circ} \mathrm{C}$ for $1.5 \mathrm{~h}$ afforded the corresponding 
phosphoramidite building blocks 17a-d in 65\%-93\% yield, to be used for oligomer assembly. Assembly of all oligonucleotides and purification was carried out as described before [33].

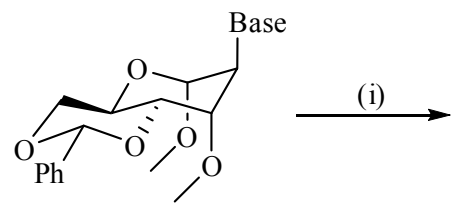

4: $\mathrm{B}=\mathrm{U} ; \mathbf{6}: \mathrm{B}=\mathrm{C}^{\mathrm{Bz}}$

9: $\mathrm{B}=\mathrm{A}^{\mathrm{Bz}} ; 14: \mathrm{B}=\mathrm{G}^{\mathrm{dmf}}$

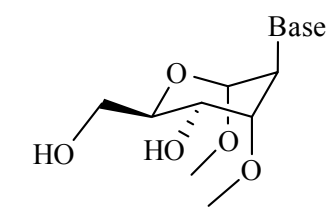

15a: $\mathrm{B}=\mathrm{U} ; 15 \mathbf{b}: \mathrm{B}=\mathrm{C}^{\mathrm{Bz}}$

15c: $B=A^{B z} ; 15 d: B=G^{d m f}$
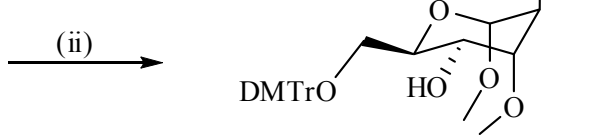

16a: $\mathrm{B}=\mathrm{U} ; 16 \mathrm{~b}: \mathrm{B}=\mathrm{C}^{\mathrm{Bz}}$

16c: $\mathrm{B}=\mathrm{A}^{\mathrm{Bz}}$; 16d: $\mathrm{B}=\mathrm{G}^{\mathrm{dmf}}$

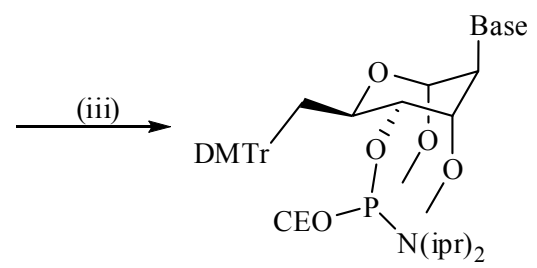

17a: Base $=\mathrm{U} ;$ 17b: Base $=\mathrm{C}^{\mathrm{Bz}}$

17c: Base $=A^{\text {Bz; }}$ 17d: Base $=\mathrm{G}^{\mathrm{dmf}}$

Reagents and Conditions: (i) AcOH: $\mathrm{H}_{2} \mathrm{O}(3: 1), 45^{\circ} \mathrm{C}, 12 \mathrm{~h}$ (50\% to 94\%); (ii) DMTrCl, pyridine, rt, $3 \mathrm{~h}$ (74\% to $93 \%$ ); (iii) (iPr) ${ }_{2} \mathrm{~N}(\mathrm{OCE}) \mathrm{PCl}$, DIPEA, DCM, $0{ }^{\circ} \mathrm{C}, 1.5 \mathrm{~h}(65 \%$ to $93 \%)$.

Scheme 3. Scheme for assembly of the different phosporamidites.

\subsection{Oligonucleotide Affinity Measurements}

First, following incorporation of a single DMANA modification into an dsRNA nonamer sequence [5'-GCGU-X*-UGCG/5'-CGCAYACGC], the respective affinities for complementary RNA were studied in a $0.1 \mathrm{M} \mathrm{NaCl}$ buffer and were compared with the melting temperatures $\left(\mathrm{T}_{\mathrm{m}}\right)$ of previously studied six-membered ring structures substituting for the ribose ring (Table 1). Within the context of all four natural bases, the HNA (anhydrohexitol) and ANA (altritol) substitutions proved advantageous and considerably stabilized the RNA helix. Where ANA modifications were either slightly less stabilizing (for pyrimidines) or more stabilizing (as with purines) versus HNA modifications, methylation of the 3'-hydroxyl moiety of ANA congeners further improved the affinity for RNA systematically with approximately $0.5^{\circ} \mathrm{C}$. However, converting the hexitol into a methyl hexopyranoside via attachment of a second "methoxy substituent" at the 1'-position as in our DMANA constructs, wiped out the advantage which was gained before in using constrained hexitol moieties. The obtained affinities of these DMANA containing constructs more or less matched those of the corresponding fully complementary RNA sequences. Incorporation of a single DMANA building block slightly destabilized the RNA duplex for substitution of a pyrimidine, but on contrast slightly stabilized the duplex in case of guanine and to a larger extent upon substitution of adenine within this sequence context (Table 1 and Figure 2, base matches).

As on average the DMNA pairing affinity to RNA was not advantageous nor really detrimental, we further studied their mismatch behavior within the same RNA nonamer constructs (5'-GCGU-X*UGCG/5'-CGCAYACGC; Figure 2) in comparison to different constructs. The graphical chart displays the destabilization in relation to the respective matched sequence as obtained for DMANA building blocks in comparison to discrimination properties for HNA and MANA ([23] and within dsRNA duplexes. Analogous discrimination properties were noted, and especially for dmanaC very selective pairing to guanosine was obtained with $-22{ }^{\circ} \mathrm{C}$ to $-24{ }^{\circ} \mathrm{C}$ of destabilization for the different mismatches. 
However, no overall advantage can be seen in terms of either pairing selectivity or universal base pairing capabilities. Hence, normal WC pairing can be assumed.

Table 1. $T_{m}$ values of complementary RNA duplexes [5'-GCGU-X*-UGCG/5'-CGCAYACGC].

\begin{tabular}{cccccc}
\hline $\mathbf{X}^{*}$ & Structure & $\mathbf{T}_{\mathbf{m}}\left({ }^{\circ} \mathbf{C}\right)$ & $\mathbf{X}^{*}$ & Structure & $\mathbf{T}_{\mathbf{m}}\left({ }^{\circ} \mathbf{C}\right)$ \\
\hline & RNA & $50.4 \pm 0.0$ & & RNA & $60.4 \pm 0.0$ \\
$\mathrm{U}^{*}$ & HNA & $53.4 \pm 0.1$ & & HNA & $62.4 \pm 0.1$ \\
& ANA & $53.0 \pm 0.2$ & $\mathrm{G}^{*}$ & ANA & $62.9 \pm 0.1$ \\
& MANA & $53.8 \pm 0.2$ & & MANA & $63.4 \pm 0.1$ \\
& DMANA & $50.6 \pm 0.2$ & & DMANA & $61.6 \pm 0.1$ \\
& RNA & $60.8 \pm 0.1$ & & RNA & $52.5 \pm 0.1$ \\
& HNA & $62.0 \pm 0.0$ & & HNA & $55.0 \pm 0.2$ \\
$\mathrm{C}^{*}$ & ANA & $60.9 \pm 0.1$ & $\mathrm{~A}^{*}$ & ANA & $56.5 \pm 0.1$ \\
& MANA & $61.4 \pm 0.0$ & & MANA & $57.0 \pm 0.1$ \\
& DMANA & $60.1 \pm 0.2$ & & DMANA & $55.5 \pm 0.1$ \\
\hline
\end{tabular}

Conditions: as determined in $100 \mathrm{mM} \mathrm{NaCl}$ buffer containing $20 \mathrm{mM} \mathrm{KH}_{2} \mathrm{PO}_{4}$ and $0.1 \mathrm{mM}$ EDTA, pH 7.5, with a duplex concentration of $4 \mu \mathrm{M}$. Annotations $\mathrm{U}^{*}, \mathrm{C}^{*}, \mathrm{~A}^{*}$ and $\mathrm{G}^{*}$ denote either a RNA, HNA, ANA, MANA or DMANA monomer respectively, versus the natural complementary base $\mathrm{Y}$.

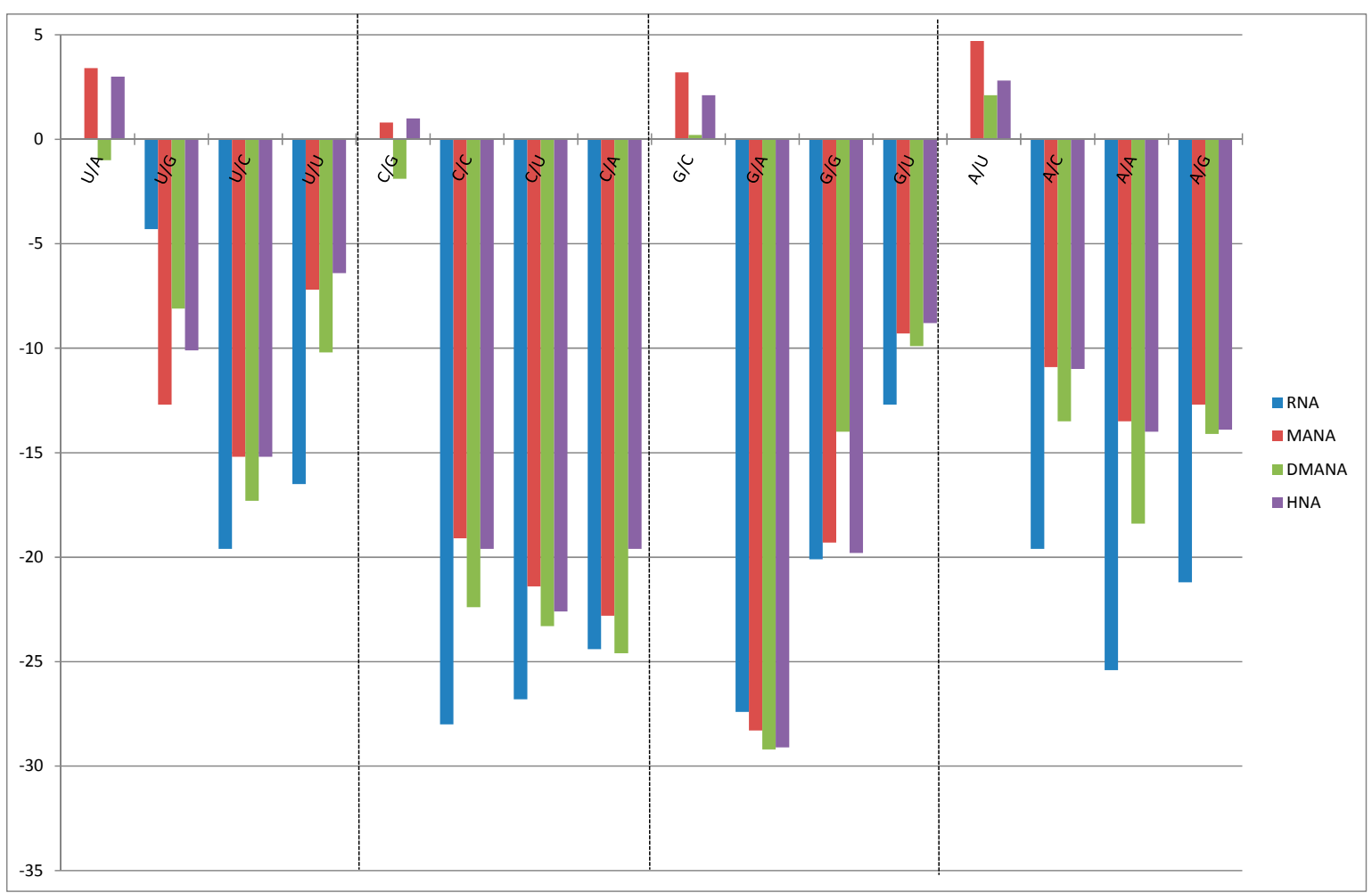

Figure 2. Base pairing selectivity for different 6-membered ring analogues. Conditions: graphical overview of the (de)stabilization of the matched and mismatched nonamer sequences following a single incorporation of a sugar modified nucleoside (MANA in red, DMANA in green and HNA in purple) wherein the selectivity of pairing is shown by destabilization of the respective mismatches. The pairing selectivity for RNA is shown in blue. 
This picture was confirmed with a second substitution within different nonamer dsRNA sequences (Table 2), with the largest destabilization noted for dmanaC building blocks $\left(-1.8{ }^{\circ} \mathrm{C} /\right.$ modification) while still an increase in stability of $1.1{ }^{\circ} \mathrm{C} /$ modification was seen with incorporation of $2 \mathrm{dmanaA}$ blocks. The stabilizing effects of the HNA and 3'-methylated ANA constructs (MANA) are included for comparative reasons. We therefore decided to prepare a fully modified DMANA octamer and hybridized it to the complementary RNA sequence (Table 2, bottom). Where the natural RNA duplex displayed a Tm of $40.6{ }^{\circ} \mathrm{C}$, the DMANA construct still paired albeit with slightly lower affinity $\left(-0.3{ }^{\circ} \mathrm{C} /\right.$ modification $)$. The different hexitol constructs on the other hand strongly increased the affinity for the RNA complement as documented before $[23,34]$. It hence can be concluded that the DMANA analogues are different from the previous hexitol series of compounds with a constrained 6-membered ring conformation fit for pairing to RNA.

Table 2. Thermal stability for RNA duplexes containing a double modification.

\begin{tabular}{|c|c|c|c|}
\hline Sequences & $\mathbf{X}^{*}$ & $\operatorname{Tm}\left({ }^{\circ} \mathrm{C}\right)$ & $\Delta \mathrm{Tm} /$ Modification $\left({ }^{\circ} \mathrm{C}\right)$ \\
\hline \multirow{4}{*}{ 5'-GCU*GUGU*CG-3' } & RNA & $55.6 \pm 0.4$ & Reference \\
\hline & MANA & $62.6 \pm 0.2$ & 3.5 \\
\hline & DMANA & $54.5 \pm 0.1$ & -0.5 \\
\hline & HNA & $60.2 \pm 0.1$ & 2.3 \\
\hline \multirow{4}{*}{ 5'-GCC*AUAC*CG-3' } & RNA & $57.1 \pm 0.1$ & Reference \\
\hline & MANA & $59.3 \pm 0.1$ & 1.1 \\
\hline & DMANA & $53.4 \pm 0.1$ & -1.8 \\
\hline & HNA & $58.2 \pm 0.1$ & 0.6 \\
\hline \multirow{4}{*}{ 5'-GCG*UUUG*CG-3' } & RNA & $51.3 \pm 0.2$ & Reference \\
\hline & MANA & $54.3 \pm 0.1$ & 1.5 \\
\hline & DMANA & $51.1 \pm 0.1$ & -0.1 \\
\hline & HNA & $53.0 \pm 0.2$ & 0.8 \\
\hline \multirow{4}{*}{ 5'-GCA*CUCA*CG-3' } & RNA & $57.1 \pm 0.1$ & Reference \\
\hline & MANA & $63.5 \pm 0.1$ & 3.2 \\
\hline & DMANA & $59.3 \pm 0.1$ & 1.1 \\
\hline & HNA & $62.1 \pm 0.1$ & 2.5 \\
\hline \multirow{5}{*}{$5^{\prime}-\mathrm{G}^{*} \mathrm{C}^{*} \mathrm{G}^{*} \mathrm{U}^{*} \mathrm{~A}^{*} \mathrm{G}^{*} \mathrm{C}^{*} \mathrm{G}^{*}-3^{\prime}$} & RNA & $40.6 \pm 0.1$ & Reference \\
\hline & MANA & $61.1 \pm 0.3$ & 2.6 \\
\hline & DMANA & $38.1 \pm 0.2$ & -0.3 \\
\hline & ANA & $59.6[34]$ & 2.4 \\
\hline & HNA & $52.0[34]$ & 1.4 \\
\hline
\end{tabular}

Conditions: $\mathrm{T}_{\mathrm{m}}$ as determined in $100 \mathrm{mM} \mathrm{NaCl}$ buffer containing $20 \mathrm{mM} \mathrm{KH}_{2} \mathrm{PO}_{4}$ and $0.1 \mathrm{mM}$ EDTA, $\mathrm{pH} 7.5$, with a duplex concentration of $4 \mu \mathrm{M}$. $\mathrm{U}^{*}, \mathrm{C}^{*}, \mathrm{~A}^{*}$ and $\mathrm{G}^{*}$ denote either a RNA, MANA, DMANA, ANA or a HNA monomer, respectively. At the bottom the results are given for the fully modified strands paired to the complementary RNA strand.

Finally, incorporation of a single DMANA building block into dsDNA 13-mer sequences [5'-CACCGX*TGCTACC-3'/3'-GTGGCYACGATGG-5'] was evaluated at $0.1 \mathrm{M}$ salt concentration (Table 3) for both match and mismatch sequences. However, a single DMANA incorporation already afforded respectively $9{ }^{\circ} \mathrm{C}$ (for dmanaU and dmanaC), $5{ }^{\circ} \mathrm{C}$ (for dmanaA) or $6{ }^{\circ} \mathrm{C}$ (for dmanaG) of destabilization for the different matched pairs within this sequence context. A slightly better result could 
be expected if we could compare the dmanaT construct instead of dmanaU in view of the stabilizing effect of a 5-methyl substituent on the base, but this still would have resulted in a destabilization of 7 to $8{ }^{\circ} \mathrm{C}$. The selectivity of pairing is adequate but gives a mixed picture, with selectivity being dependent probably on the base and the sequence context. In view of the fairly strong destabilization versus DNA sequences it is clear however that these DMANA blocks do not have a DNA like conformation.

Table 3. Hybridization studies following incorporation into a DNA strand.

\begin{tabular}{ccccccccc}
\hline $\mathbf{Y}$ & \multicolumn{2}{c}{$\mathbf{A}$} & \multicolumn{3}{c}{$\mathbf{T}$} & \multicolumn{3}{c}{$\mathbf{G}$} \\
\hline $\mathbf{X}^{*}(\mathbf{X})$ & $\mathbf{T}_{\mathbf{m}}$ & $\boldsymbol{\Delta} \mathbf{T}_{\mathbf{m}}$ & $\mathbf{T}_{\mathbf{m}}$ & $\boldsymbol{\Delta} \mathbf{T}_{\mathbf{m}}$ & $\mathbf{T}_{\mathbf{m}}$ & $\boldsymbol{\Delta} \mathbf{T}_{\mathbf{m}}$ & $\mathbf{T}_{\mathbf{m}}$ & $\boldsymbol{\Delta} \mathbf{T}_{\mathbf{m}}$ \\
\hline $\mathrm{U}^{*}$ & 47.7 & - & 40.9 & -6.8 & 41.7 & -6.0 & 38.3 & -9.4 \\
$\mathrm{~T}$ & 57.1 & - & 46.7 & -10.4 & 50.3 & -6.8 & 44.2 & -12.9 \\
$\mathrm{~A}^{*}$ & 41.9 & -10.8 & 52.7 & - & 45.3 & -7.4 & 41.4 & -11.3 \\
$\mathrm{~A}$ & 46.6 & -10.7 & 57.3 & - & 52.9 & -4.4 & 44.4 & -12.9 \\
$\mathrm{C}^{*}$ & 41.8 & -10.3 & 40.8 & -11.3 & 52.1 & - & 38.5 & -13.6 \\
$\mathrm{C}$ & 44.4 & -16.5 & 45.6 & -15.3 & 60.9 & - & 40.6 & -20.3 \\
$\mathrm{G}^{*}$ & 42.9 & -11.0 & 48.9 & -5.0 & 46.0 & -7.9 & 53.9 & - \\
$\mathrm{G}$ & 51.6 & -8.4 & 51.0 & -9.0 & 53.5 & -6.5 & 60.0 & - \\
\hline
\end{tabular}

Conditions: $\mathrm{T}_{\mathrm{m}}$ values are provided for a single incorporation of a DMANA $\left(\mathrm{X}^{*}\right)$ modification into a mixed DNA sequence [5'-CACCGX*TGCTACC-3'/3'-GTGGCYACGATGG-5'] for the match and the different mismatch sequences $(\mathrm{Y})$ at $0.1 \mathrm{M}$ salt and $4 \mathrm{M}$ of duplex concentration.

\subsection{Discussion}

The MedChem group of the Rega Institute has already been elaborating for many years on nucleoside analogues with a 6-membered ring system substituting for ribose for various applications. Especially the analogues with a 1,5-anhydrohexitol ring having the base at the $\mathrm{C} 2$ ' in syn orientation with the remaining hydroxymethyl substituent (HNA, ANA and MANA) turned out to be well pre-organized for pairing with RNA, and are thus strongly stabilizing for RNA duplexes. Several biological studies have been undertaken with both HNA and ANA [22,35,36] and interesting results were obtained more recently regarding their use as xeno-nucleic acids [37,38]. Highest affinities so far however were obtained with MANA building blocks [23]. We therefore started to study the influence of DMANA analogues carrying an additional methoxy substituent on the 6-membered ring system. However, as shown by the various $\mathrm{T}_{\mathrm{m}}$ studies, incorporation of the new modification does not further increase the affinity for RNA, but overall rather tends to slightly destabilize dsRNA complexes, while strongly destabilizing DNA upon incorporation. Therefore the modification still resembles more closely RNA monomers with their 3'-endo conformation as in RNA duplexes.

These findings are further corroborated by inserting in silico a modified building block into a dsRNA. As can be seen in Figure 3, no steric hindrance occurs when substituting a DMANA residue having two OMe groups at the sugar 1' and 3' positions for a uridine into an RNA duplex for which the model of Mooers was used [39]. The HNA sugar conformation upon pairing with RNA is ${ }^{1} \mathrm{C}_{4}$ having an axial base orientation. Likewise, for the DMANA structure incorporated into the dsRNA, both methoxy substituents likewise are oriented axially with no apparent steric clashes. However, it is well known that apart from forces like the anomeric effect, substituents in 6-membered rings prefer the equatorial 
orientation to avoid 1,3-diaxial interactions. Energy calculations for the monomers using Amber force field [40] indeed show a slight preference for having the base and both methoxy groups in an all-equatorial configuration (with 4'-OH and 6'- $\mathrm{CH}_{2} \mathrm{OH}$ in axial orientation), opposite to what is found for HNA and ANA building blocks with an axial oriented heterocyclic base. Increasing the number of OMe substituents therefore may destabilize the ${ }^{1} \mathrm{C}_{4}$ chair conformation giving preference to ${ }^{4} \mathrm{C}_{1}$, which is less compatible with the RNA duplex. Hence, the energy penalty to preserve the DMANA monomer in a ${ }^{1} \mathrm{C}_{4}$ conformation to allow for pairing within a dsRNA strand, might upset the entropic gain as expected of a pre-organized monomer.

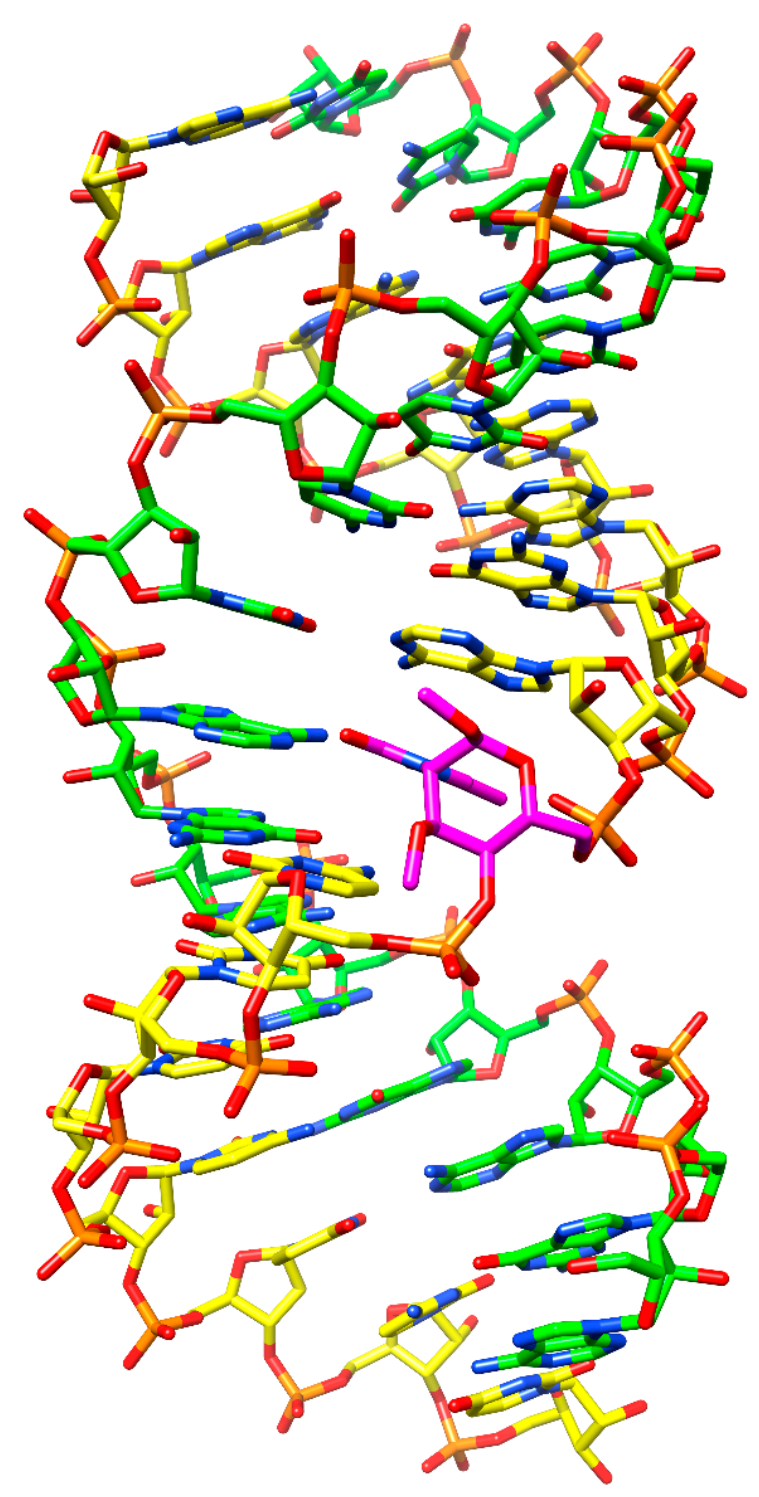

Figure 3. RNA duplex following insertion of a DMANA modification (DMANA modification in purple; picture generated using Chimera (UCSF Chimera-a visualization system for exploratory research and analysis [41]).

Table 4 indeed shows the largest energy difference for both chair conformations for DMANA constructs. This energetic penalty for a forced change in conformation could be the basis of the reduced fitness of DMANA analogues for pairing with RNA. 
Table 4. Energy calculations for monomers with different scaffold.

\begin{tabular}{cccccc}
\hline $\begin{array}{c}\text { Base and OMe } \\
\text { Orientation }\end{array}$ & Axial & Equatorial & $\begin{array}{c}\text { Base and OMe } \\
\text { Orientation }\end{array}$ & Axial & Equatorial \\
\hline HNA & -205.31 & -205.79 & MANA & -195.22 & -200.35 \\
ANA & -200.58 & -198.19 & DMANA & -187.62 & -194.82 \\
Chair & ${ }^{1} \mathrm{C}_{4}$ & ${ }^{4} \mathrm{C}_{1}$ & Chair & ${ }^{1} \mathrm{C}_{4}$ & ${ }^{4} \mathrm{C}_{1}$ \\
\hline
\end{tabular}

Conditions: Final energies in kcal/mol are shown following minimization using Amber force field. Nucleotides all have a thymine base, uncharged residues (phosphate groups protonated), with parametrization via antechamber, Gaff force field, 5000 steps of energy minimization, born solvation energy model.

\section{Experimental Section}

\subsection{General}

All chemicals including methylglucopyranoside were provided by Sigma-Aldrich (Diegem, Belgium) or Acros Organics (Geel, Belgium) and were of the highest quality. ${ }^{1} \mathrm{H}$ and ${ }^{13} \mathrm{C}-\mathrm{NMR}$ spectra were determined with a 300, 500 and $600 \mathrm{MHz}$ Varian Gemini apparatus (currently Agilent Technologies, Santa Clara, CA, USA) with tetramethylsilane as internal standard for the ${ }^{1} \mathrm{H}$ NMR spectra ( $\mathrm{s}=$ singlet, $\mathrm{d}=$ doublet, $\mathrm{dd}=$ double doublet, $\mathrm{t}=$ triplet, $\mathrm{br} . \mathrm{s}=$ broad signal, $\mathrm{m}=$ multiplet) and the solvent signal; $\mathrm{CD}_{3} \mathrm{OD}-d_{4}(\delta=48.9 \mathrm{ppm})$, DMSO- $d_{6}(\delta=39.6 \mathrm{ppm})$ or $\mathrm{CDCl}_{3}(\delta=76.9 \mathrm{ppm})$ for the ${ }^{13} \mathrm{C}-\mathrm{NMR}$ spectra. Exact mass measurements were performed with a quadrupole/orthogonal acceleration time-of-flight tandem mass spectrometer (qTOF2, Micromass, Manchester, UK) fitted with a standard electrospray ionization (ESI) interface. All solvents were carefully dried or bought as such.

\subsection{1',5';2',3'-Dianhydro-4',6'-O-benzylidene-1'-O-methyl-D-allopyranoside (2)}

To a solution of the 4',6'- $O$-benzylidene-2',3'-ditosyl intermediate (10.0 g, $17 \mathrm{mmol})$ in $\mathrm{CH}_{2} \mathrm{Cl}_{2}$ $(80 \mathrm{~mL})$ was added $\mathrm{NaOMe}(5.3 \mathrm{M}$ in $\mathrm{MeOH}, 12.8 \mathrm{~mL}, 67.8 \mathrm{mmol})$. After stirring for overnight at room temperature, the reaction mixture was concentrated and the residue was dissolved in $\mathrm{CH}_{2} \mathrm{Cl}_{2}(150 \mathrm{~mL})$, and washed twice with brine $(50 \mathrm{~mL})$. The aqueous layer was again extracted with $\mathrm{CH}_{2} \mathrm{Cl}_{2}(2 \times 80 \mathrm{~mL})$. Combined organic layers were dried over anhydrous $\mathrm{Na}_{2} \mathrm{SO}_{4}$, filtered and evaporated to get pure epoxide 2 (4.45 g, 99\%). ${ }^{1} \mathrm{H}-\mathrm{NMR}\left(300 \mathrm{MHz}, \mathrm{CDCl}_{3}\right): \delta 7.60-7.33(\mathrm{~m}, 5 \mathrm{H}, \mathrm{Ar}-\mathrm{H}), 5.60(\mathrm{~d}, J=6.1 \mathrm{~Hz}, 1 \mathrm{H}$, Ph- $\underline{\mathrm{CH}}$ ), 4.92 (dd, $\left.J=6.1,2.7 \mathrm{~Hz}, 1 \mathrm{H}, 1^{\prime}-\mathrm{H}\right), 4.32-4.22$ (m, 1H, 6'-He), 4.18-4.05 (m, 1H, 5-H), 3.98 (dd, $J=9.0,6.2 \mathrm{~Hz}, 1 \mathrm{H}, 4-\mathrm{H}), 3.71$ (m, 1H, 6-Ha), 3.58-3.45 (m, 5H, 2'-H, O-Me). ${ }^{13} \mathrm{C}-\mathrm{NMR}(75 \mathrm{MHz}$, $\left.\mathrm{CDCl}_{3}\right): \delta 137.11\left(\mathrm{Ar}-\mathrm{C}_{\mathrm{i}}\right) ; 129.19 ; 128.28\left(\mathrm{Ar}-\mathrm{C}_{\mathrm{p}+\mathrm{o}}\right) ; 126.27\left(\mathrm{Ar}-\mathrm{C}_{\mathrm{m}}\right) ; 102.71(\mathrm{Ph}-\underline{\mathrm{C}}) ; 95.27\left(\mathrm{C}-1^{\prime}\right) ; 77.83$ $\left(\mathrm{C}-4^{\prime}\right)$; $68.86\left(\mathrm{C}-6^{\prime}\right) ; 59.99\left(\mathrm{C}-5^{\prime}\right)$; $55.82(\mathrm{OMe}) ; 53.07$ (C-3'); 50.66 (C-2'); HRMS calcd. for $\mathrm{C}_{14} \mathrm{H}_{16} \mathrm{O}_{5} \mathrm{Na}^{+}[\mathrm{M}+\mathrm{Na}]^{+} 287.0890$, found 287.0891 .

\subsection{4',6'-O-Benzylidene-1'-O-methyl-2'-deoxy-2'-(uracil-l-yl)-D-altropyranoside (3)}

To a solution of uracil $(4.62 \mathrm{~g}, 38.6 \mathrm{mmol})$ in dry DMF $(30 \mathrm{~mL})$ was added $\mathrm{NaH}(60 \%$ dispersion in oil, $1.29 \mathrm{~g}, 41.2 \mathrm{mmol}$ ). The reaction mixture was heated at $120^{\circ} \mathrm{C}$ under an argon atmosphere for $1 \mathrm{~h}$ and to this reaction mixture epoxide $2(3.4 \mathrm{~g}, 12.9 \mathrm{mmol})$ in dry DMF $(20 \mathrm{~mL})$ was added and stirring was continued for overnight at same temperature. The reaction mixture was then cooled and evaporated 
to dryness. The residue was dissolved in ethyl acetate $(150 \mathrm{~mL})$ and the organic layer was washed with a saturated aqueous $\mathrm{NaHCO}_{3}$ solution $(2 \times 50 \mathrm{~mL})$. The aqueous layer was again extracted with EtOAc $(3 \times 50 \mathrm{~mL})$. The combined organic layers were washed with brine $(2 \times 50 \mathrm{~mL})$, dried over $\mathrm{Na}_{2} \mathrm{SO}_{4}$, and concentrated under vacuo and purification by silica gel column chromatography (elution with $2 \% \mathrm{MeOH}$ in DCM) afforded $3(1.61 \mathrm{~g}, 33 \%)$ as a white foam while recovering a large part of the starting epoxide 2 (1.94 g, 40\% yield). ${ }^{1} \mathrm{H}-\mathrm{NMR}\left(500 \mathrm{MHz}, \mathrm{CDCl}_{3}\right): \delta 7.75(\mathrm{~d}, J=8.1 \mathrm{~Hz}, 1 \mathrm{H}, 6-\mathrm{H}), 7.49-7.41(\mathrm{~m}, 2 \mathrm{H}$, Ar-H), 7.39-7.30 (m, 3H, Ar-H), 5.77 (d, J=8.1 Hz, 1H, 5-H), 5.62 (s, 1H, Ph- $\underline{\mathrm{CH}}), 4.83$ (s, 1H, 1'-H), 4.81 (s, 1H, 2'-H), $4.48-4.38$ (m, 2H, 5'-H, 6'-He), 4.16 (brs, 1H, 3'-H), 3.81 (t, J=9.9 Hz, 1H, 6'-Ha), 3.69 (dd, $\left.J=9.9,2.4 \mathrm{~Hz}, 1 \mathrm{H}, 4{ }^{\prime}-\mathrm{H}\right), 3.41-3.51$ (m, 4H, OMe, $\left.-\mathrm{OH}\right) .{ }^{13} \mathrm{C}-\mathrm{NMR}\left(125 \mathrm{MHz}, \mathrm{CDCl}_{3}\right): \delta$ 163.08 (C-4); 150.60 (C-2); 141.14 (C-6); $136.81\left(\mathrm{Ar}-\mathrm{C}_{\mathrm{i}}\right) ; 129.26\left(\mathrm{Ar}-\mathrm{C}_{\mathrm{p}}\right) ; 128.28\left(\mathrm{Ar}-\mathrm{C}_{\mathrm{m}}\right) ; 126.18$ (Ar-Co); 102.91 (C-5); 102.27 (Ph- $\underline{\mathrm{C}}) ; 98.99$ (C-1'); 75.61 (C-3'); 68.94 (C-4'); 67.02 (C-6'); 58.19 (C-5'); 57.91 (OMe); 55.97(C-2'). HRMS calcd. for $\mathrm{C}_{18} \mathrm{H}_{20} \mathrm{~N}_{2} \mathrm{O}_{7} \mathrm{Na}^{+}[\mathrm{M}+\mathrm{Na}]^{+}$399.1163, found 399.1156.

\subsection{4',6'-O-Benzylidene-1',3'-di-O-methyl-2'-deoxy-2'-(uracil-l-yl)-D-altropyranoside (4)}

To a solution of $\mathbf{3}(1.51 \mathrm{~g}, 4.0 \mathrm{mmol})$ in dry THF $(15 \mathrm{~mL})$ was added $\mathrm{NaH}(60 \%$ dispersion in oil, $404 \mathrm{mg}, 12.04 \mathrm{mmol})$ at $0{ }^{\circ} \mathrm{C}$ and the reaction mixture was stirred at $0{ }^{\circ} \mathrm{C}$ for $1 \mathrm{~h}$ under argon atmosphere. Methyl iodide $(0.37 \mathrm{~mL}, 6.02 \mathrm{mmol})$ in dry THF $(1 \mathrm{~mL})$ was added and stirring was continued for another $1 \mathrm{~h}$ at the same temperature. The reaction mixture was quenched with $5 \mathrm{~mL} \mathrm{MeOH}$. The solution was concentrated and dissolved in ethyl acetate $(150 \mathrm{~mL})$ and washed with saturated aqueous $\mathrm{NaHCO}_{3}$ $(150 \mathrm{~mL})$. The aqueous layer was again extracted with ethyl acetate $(3 \times 50 \mathrm{~mL})$. The combined the organic layers were dried over $\mathrm{Na}_{2} \mathrm{SO}_{4}$, filtered, concentrated under vacuo, and purification by silica gel column chromatography (elution with $2 \% \mathrm{MeOH}$ in DCM) afforded the dimethylated nucleoside 4 (1.01 g, 65\%). ${ }^{1} \mathrm{H}-\mathrm{NMR}\left(500 \mathrm{MHz}, \mathrm{CDCl}_{3}\right): \delta 9.41\left(\mathrm{~s}, 1 \mathrm{H}, \mathrm{N}^{3}-\mathrm{H}\right), 7.80(\mathrm{~d}, J=8.2 \mathrm{~Hz}, 1 \mathrm{H}, 6-\mathrm{H})$, 7.47-7.35 (m, 5H, Ar-H), 5.80 (dd, $J=8.1,1.7 \mathrm{~Hz}, 1 \mathrm{H}, 5-\mathrm{H}), 5.55$ (s, 1H, Ph- $\underline{\mathrm{CH}}$ ), 4.90 (d, $J=1.7 \mathrm{~Hz}$, $\left.1 \mathrm{H}, 1^{\prime}-\mathrm{H}\right), 4.80$ (s, 1H, 2'-H), 4.48-4.36 (m, 2H, 6'-He, 3'-H), 3.77 (t, $J=10.3 \mathrm{~Hz}, 1 \mathrm{H}, 6$ '-Ha),3.72-3.67 (m, 2H, 4'-H, 5'-H), 3.62 (s, 3H, OMe), 3.46 (s, 3H, OMe). ${ }^{13} \mathrm{C}-\mathrm{NMR}\left(125 \mathrm{MHz}, \mathrm{CDCl}_{3}\right): \delta 162.98$ (C-4); 150.39 (C-2); 141.18 (C-6); $137.06($ Ar-C $)$; $129.20\left(\right.$ Ar- $\left.\mathrm{C}_{\mathrm{p}}\right) ; 128.28\left(\mathrm{Ar}-\mathrm{C}_{\mathrm{m}}\right) ; 126.21\left(\mathrm{Ar}-\mathrm{C}_{\mathrm{o}}\right)$; 102.86 (C-5); 102.48 (Ph- $\underline{\mathrm{C}}) ; 98.84$ (C-1'); 76.06 (C-3'); 75.95 (C-4'); 69.11 (C-5'); 59.59 (C-6'); 58.56 (OMe); $55.94(\mathrm{OMe})$; 55.81(C-2'). HRMS calcd. for $\mathrm{C}_{19} \mathrm{H}_{23} \mathrm{~N}_{2} \mathrm{O}_{7}[\mathrm{M}+\mathrm{H}]^{+}$391.1500, found 391.1494.

\subsection{4',6'-O-Benzylidene-1',3'-di-O-methyl-2-deoxy-2'-(cytosin-1-yl)-D-altropyranoside (5)}

A solution of triazole $(1.05 \mathrm{~g}, 15.2 \mathrm{mmol})$ and phosphorus oxychloride $(0.3 \mathrm{~mL}, 3.18 \mathrm{mmol})$ was prepared in pyridine $(8 \mathrm{~mL})$ at $0{ }^{\circ} \mathrm{C}$. Triethylamine $(2.03 \mathrm{~mL}, 14.5 \mathrm{mmol})$ was added dropwise at $0{ }^{\circ} \mathrm{C}$ and the solution was stirred $30 \mathrm{~min}$. The uracil derivative $4(0.650 \mathrm{~g}, 1.66 \mathrm{mmol})$ dissolved in dry pyridine $(8 \mathrm{~mL})$ was added at $0{ }^{\circ} \mathrm{C}$ and the solution was stirred for $2 \mathrm{~h}$ at room temperature and concentrated and co-evaporated with toluene $(2 \times 20 \mathrm{~mL})$. The crude product was dissolved with DCM $(150 \mathrm{~mL})$ and washed twice with brine $(60 \mathrm{~mL})$. The aqueous layer was extracted with DCM $(30 \mathrm{~mL})$. Combined organic layers were dried over anhydrous $\mathrm{Na}_{2} \mathrm{SO}_{4}$, filtered and evaporated. The residue was dissolved in 1,4-dioxane $(30 \mathrm{~mL})$, cooled to $0{ }^{\circ} \mathrm{C}$ and aqueous ammonia $25 \%(13 \mathrm{~mL})$ were added. The solution was left overnight at RT. The solution was evaporated and co-evaporated with toluene $(3 \times 20 \mathrm{~mL})$. The residue was purified by silica gel column chromatography (elution with $10 \% \mathrm{MeOH} /$ dichloromethane) 
and afforded the dimethylated cytidine analog $5(377 \mathrm{mg}, 58 \%)$ as a white foam. ${ }^{1} \mathrm{H}-\mathrm{NMR}(500 \mathrm{MHz}$, $\left.\mathrm{CD}_{3} \mathrm{OD}\right): \delta 7.91(\mathrm{~d}, J=7.5 \mathrm{~Hz}, 1 \mathrm{H}, 6-\mathrm{H}), 7.50-7.42(\mathrm{~m}, 2 \mathrm{H}, \mathrm{Ar}-\mathrm{H}), 7.38-7.26$ (m, 3H, Ar-H), 5.95 (d, $J=7.5 \mathrm{~Hz}, 1 \mathrm{H}, 5-\mathrm{H}), 5.63$ (s, 1H, Ph- $\underline{\mathrm{CH}}), 4.93$ (s, 1H, 2'-H), 4.91 (d, J=2.1 Hz, 1H, 1'-H), 4.34-4.30 (m, $1 \mathrm{H}, 6$ '-He), 4.28 (dd, $J=9.9,5.3 \mathrm{~Hz}, 1 \mathrm{H}, 5 '-\mathrm{H}), 3.84$ (dd, $J=11.0,2.3 \mathrm{~Hz}, 1 \mathrm{H}, 6$ '-Ha), 3.81 (dd, $J=6.6$, $\left.2.3 \mathrm{~Hz}, 1 \mathrm{H}, 4^{\prime}-\mathrm{H}\right), 3.67$ (t, $\left.J=2.3 \mathrm{~Hz}, 1 \mathrm{H}, 3{ }^{\prime}-\mathrm{H}\right), 3.57$ (s, 3H, OMe), 3.42 (s, 3H, OMe). ${ }^{13} \mathrm{C}-\mathrm{NMR}$ (125 MHz, CD 3 OD): $\delta 167.49$ (C-4); 158.15 (C-2); 144.10 (C-6), $139.09\left(\mathrm{Ar}_{-} \mathrm{C}_{\mathrm{i}}\right), 129.97\left(\mathrm{Ar}-\mathrm{C}_{\mathrm{p}}\right), 129.07$ (Ar- $\left.\mathrm{C}_{\mathrm{m}}\right), 127.44$ (Ar- $\left.\mathrm{C}_{\mathrm{o}}\right), 103.41$ (Ph- $\left.\underline{\mathrm{C}}\right), 100.28$ (C-5), 96.46 (C-1'), 77.40 (C-3'), 76.86 (C-4'), 70.05 (C-6'), 59.93 (C-5'), $59.13(\mathrm{OMe}), 57.45(\mathrm{OMe}), 55.84\left(\mathrm{C}-2^{\prime}\right)$. HRMS calcd. for $\mathrm{C}_{19} \mathrm{H}_{24} \mathrm{~N}_{3} \mathrm{O}_{6}{ }^{+}[\mathrm{M}+\mathrm{H}]^{+}$ 390.1654 , found 390.1653 .

\subsection{4', 6'-O-Benzylidene-1',3'-O-methyl-2'-deoxy-2'-(N'-benzoylcytosin-1-yl)-D-altropyranoside (6)}

The analog 5 (0.35 g, $0.9 \mathrm{mmol})$ was co-evaporated with dry pyridine $(6 \mathrm{~mL})$, dissolved in dry pyridine $(4 \mathrm{~mL})$, and cooled at $0{ }^{\circ} \mathrm{C}$. Benzoyl chloride $(0.314 \mathrm{~mL}, 2.7 \mathrm{mmol})$ was added and the solution was allowed to come to RT. The solution was stirred for $3 \mathrm{~h}$ at RT. The mixture was cooled to $0{ }^{\circ} \mathrm{C}$ and water $(0.25 \mathrm{~mL})$ was added. Then, aqueous ammonia $25 \%(2 \mathrm{~mL})$ was added and the solution was stirred for $30 \mathrm{~min}$ at RT. The volatiles were removed under reduced pressure and co-evaporated, each time with toluene $(3 \times 5 \mathrm{~mL})$. The residue was adsorbed on silica by co-evaporation from DCM and purified by silica column chromatography (elution with $2 \% \mathrm{MeOH} / \mathrm{DCM}$ ) affording the protected nucleoside 6 (370 mg, 83\% yield) as a white foam. ${ }^{1} \mathrm{H}-\mathrm{NMR}\left(300 \mathrm{MHz}, \mathrm{CDCl}_{3}\right): \delta 8.24(\mathrm{~d}, J=7.5 \mathrm{~Hz}, 1 \mathrm{H}, 6-\mathrm{H}), 7.94$ (d, $J=7.3 \mathrm{~Hz}, 2 \mathrm{H}, \mathrm{Bz}-\mathrm{H}), 7.70-7.33$ (m, 9H, 5-H, Ar-H, Bz-H), 5.56 (s, 1H, Ph- $\underline{\mathrm{CH}}$ ), 5.12 (d, J=1.6 Hz, 1H, 1'-H), 4.90 (s, 1H, 2'-H), 4.55-4.37 (m, 2H, 5'-H, 6'-He), 3.86-3.71 (m, 2H, 6'-Ha, 3'-H), 3.74 (dd, $\left.J=9.5,3.1 \mathrm{~Hz}, 1 \mathrm{H}, 4{ }^{\prime}-\mathrm{H}\right), 3.68$ (s, 3H, OMe), 3.49 (s, 3H, OMe). ${ }^{13} \mathrm{C}-\mathrm{NMR}\left(75 \mathrm{MHz}, \mathrm{CDCl}_{3}\right): \delta 167.76$ (PhCONH); 162.14 (C-4); 137.11 (C-2); 133.34 (C-6); 129.18, 129.08, 128.28, 127.60, 126.23 (Ar-C, Bz-C); 102.48 (Ph- $\underline{\text { ) }) ; ~} 99.00$ (C-5); 97.14 (C-1'), 78.35 (C-3'), 75.77 (C-4'); 75.33 (C-5'); 69.20 (C-6'); $59.51(\mathrm{OMe}) ; 58.72(\mathrm{OMe}) ; 56.03\left(\mathrm{C}^{\prime}\right)$. HRMS calcd. for $\mathrm{C}_{26} \mathrm{H}_{28} \mathrm{~N}_{3} \mathrm{O}_{7}^{+}[\mathrm{M}+\mathrm{H}]^{+}$494.1922, found 494.1919.

\subsection{4',6'-O-Benzylidene-1'-O-methyl-2'-deoxy-2'-(adenin-9-yl)-D-altropyranoside (7)}

To a solution of adenine (3.22 g, $23.85 \mathrm{mmol})$ in dry DMF $(40 \mathrm{~mL})$ was added $\mathrm{NaH}(60 \%$ dispersion in oil, $890 \mathrm{mg}, 22.26 \mathrm{mmol})$. The reaction mixture was heated at $90^{\circ} \mathrm{C}$ under argon atmosphere for $1 \mathrm{~h}$, after which the epoxide $2(2.1 \mathrm{~g}, 7.95 \mathrm{mmol})$ in dry DMF $(15 \mathrm{~mL})$ was added and stirring was continued overnight at $120^{\circ} \mathrm{C}$. The reaction mixture was quenched with $\mathrm{MeOH}(15 \mathrm{~mL})$ and following evaporation the residue was partitioned between EtOAc and saturated aqueous $\mathrm{NaHCO}_{3}$ solution. The organic layer was separated and the aqueous layer was extracted with EtOAc $(3 \times 50 \mathrm{~mL})$. The combined the organic layers were dried over $\mathrm{Na}_{2} \mathrm{SO}_{4}$, filtered, concentrated in vacuo, and purification by normal silica gel column chromatography (elution with $3 \% \mathrm{MeOH}$ in DCM) afforded compound 7 (2.37 g, 75\%). ${ }^{1} \mathrm{H}-\mathrm{NMR}\left(300 \mathrm{MHz}, \mathrm{CDCl}_{3}\right): \delta 8.30(\mathrm{~s}, 1 \mathrm{H}, 8-\mathrm{H}), 8.18(\mathrm{~s}, 1 \mathrm{H}, 2-\mathrm{H}), 7.50-7.29(\mathrm{~m}, 5 \mathrm{H}, \mathrm{Ar}-\mathrm{H}), 6.00$ (s, $\left.2 \mathrm{H},-\mathrm{NH}_{2}\right), 5.55$ (s, 1H, Ph- $\left.\underline{\mathrm{CH}}\right), 5.15$ (s, 1H, 1'-H), 5.07 (s, 1H, 2'-H), 4.64- 4.52 (m, 1H, 5'-H), 4.46 (dd, $J=9.9,4.7 \mathrm{~Hz}, 1 \mathrm{H}, 6$ '-He), 4.33 (brs, 1H, 3'-H), 3.86 (t, $J=9.9 \mathrm{~Hz}, 1 \mathrm{H}, 6$ '-Ha), 3.73 (d, $J=8.3 \mathrm{~Hz}$, 1H, 4'-H), 3.54 (s, 3H, OMe). ${ }^{13} \mathrm{C}-\mathrm{NMR}\left(75 \mathrm{MHz}, \mathrm{CDCl}_{3}\right): \delta 155.60$ (C-6); 153.44 (C-2); 149.77 (C-4); 138.45 (C-8); 136.86 (C-5); 129.28, 128.26, 126.15, 118.89 (Ar-C); 102.35 (Ph- $\underline{\text { C) }}$; 99.66 (C-1'); 75.87 
(C-5'); $69.14\left(\mathrm{C}-3^{\prime}\right) ; 67.03\left(\mathrm{C}^{\prime} 4^{\prime}\right) ; 58.52\left(\mathrm{C}^{\prime} 6^{\prime}\right) ; 57.18$ (OMe); 56.13 (C-2'). HRMS calcd. for $\mathrm{C}_{19} \mathrm{H}_{22} \mathrm{~N}_{5} \mathrm{O}_{5}^{+}[\mathrm{M}+\mathrm{H}]^{+} 400.1615$, found 400.1613 .

\subsection{4',6'-O-Benzylidene-1',3'-di-O-methyl-2'-deoxy-2'-(adenin-9-yl)-D-altropyranoside (8)}

The adenine analog 7 (2.36 g, $5.9 \mathrm{mmol})$ was co-evaporated with dry DMF (40 mL).The foam was dissolved in dry DMF $(70 \mathrm{~mL})$, cooled to $-78{ }^{\circ} \mathrm{C}$ and $\mathrm{NaH}(330 \mathrm{mg}, 8.28 \mathrm{mmol})$ was added and the mixture was stirred at $-78{ }^{\circ} \mathrm{C}$ for $30 \mathrm{~min}$ under argon. Subsequently, methyl iodide $(0.590 \mathrm{~mL}, 9.46 \mathrm{mmol})$ was dissolved in dry DCM $(20 \mathrm{~mL})$ and the solution was added drop wise over $30 \mathrm{~min}$ to the reaction mixture at the same temperature. Stirring was continued for another $4.5 \mathrm{~h}$ at $-78{ }^{\circ} \mathrm{C}$ and at $-30{ }^{\circ} \mathrm{C}$ for an additional $1 \mathrm{~h}$ before quenching of the reaction with $\mathrm{MeOH}(10 \mathrm{~mL})$. The solution was warmed to RT and concentrated to dryness under vacuum. The residue was dissolved in ethyl acetate $(150 \mathrm{~mL})$ and washed with aqueous saturated $\mathrm{NaHCO}_{3}(130 \mathrm{~mL})$. The organic layer was then washed with brine $(130 \mathrm{~mL})$, and the combined aqueous layers were again extracted with ethyl acetate $(2 \times 150 \mathrm{~mL})$. The combined organic layers were dried over $\mathrm{Na}_{2} \mathrm{SO}_{4}$, filtered, and concentrated. Purification by silica column chromatography ( $0 \%-3 \% \mathrm{MeOH} / \mathrm{DCM})$ afforded the methylated nucleoside 8 (1.84 g, 75.4\%). ${ }^{1} \mathrm{H}-\mathrm{NMR}\left(500 \mathrm{MHz}, \mathrm{CDCl}_{3}\right): \delta 8.39(\mathrm{~s}, 1 \mathrm{H}, 8-\mathrm{H}), 8.20(\mathrm{~s}, 1 \mathrm{H}, 2-\mathrm{H}), 7.47-7.40(\mathrm{~m}, 2 \mathrm{H}, \mathrm{Ar}-\mathrm{H})$, 7.37-7.31 (m, 3H, Ar-H), 5.92 (s, 2H, -NH2), 5.49 (s, 1H, Ph- $\underline{\mathrm{CH}}$ ), 5.15 (d, J=2.5 Hz, 1H, 1'-H), 5.07 (s, 1H, 2'-H), 4.54 (td, $\left.J=10.1,5.3 \mathrm{~Hz}, 1 \mathrm{H}, 5^{\prime}-\mathrm{H}\right), 4.44$ (dd, $\left.J=10.5,5.3 \mathrm{~Hz}, 1 \mathrm{H}, 6-\mathrm{He}\right), 3.88$ (t, $J=2.6 \mathrm{~Hz}$, 1H, 3'-H), 3.83 (t, $\left.J=10.5 \mathrm{~Hz}, 1 \mathrm{H}, 6^{\prime}-\mathrm{Ha}\right), 3.79$ (dd, $\left.J=9.8,2.5 \mathrm{~Hz}, 1 \mathrm{H}, 4{ }^{\prime}-\mathrm{H}\right), 3.71$ (s, 3H, OMe), 3.52 (s, 3H, OMe). ${ }^{13} \mathrm{C}-\mathrm{NMR}\left(125 \mathrm{MHz}, \mathrm{CDCl}_{3}\right): \delta 155.57$ (C-6); 153.54 (C-2); 149.99 (C-4); 138.56 (C-8); 137.11, 129.15, 128.26, 126.16 (Ar-C); 119.10 (C-5); 102.48 (Ph- - ); 99.47 (C-1'); 76.25 (C-5'); 76.19 (C-3'); 69.26 (C-4'); 60.06 (C-6'); 58.81 (OMe); 56.06 (OMe); 55.05 (C-2'). HRMS calcd. for $\mathrm{C}_{20} \mathrm{H}_{24} \mathrm{~N}_{5} \mathrm{O}_{5}^{+}[\mathrm{M}+\mathrm{H}]^{+}$414.1772, found 414.1767.

\subsection{4',6'-O-Benzylidene-1',3'-di-O-methyl-2'-deoxy-2'-(N'-benzoyladenin-9-yl)-D-altropyranoside (9)}

The obtained analog 8 (1.59 g, $3.85 \mathrm{mmol})$ was co-evaporated with dry pyridine $(2 \mathrm{~mL})$, dissolved in dry pyridine $(16 \mathrm{~mL})$, and cooled at $0{ }^{\circ} \mathrm{C}$. Benzoyl chloride $(1.34 \mathrm{~mL}, 11.54 \mathrm{mmol})$ was added and the solution was allowed to come to RT. The solution was stirred $3 \mathrm{~h}$ at RT. The mixture was cooled to $0{ }^{\circ} \mathrm{C}$ and water $(4 \mathrm{~mL})$ was added. Then, aqueous ammonia $25 \%(8 \mathrm{~mL})$ was added and the solution was stirred $30 \mathrm{~min}$ at RT. The volatiles were removed under reduced pressure and co-evaporated, each time with toluene $(3 \times 25 \mathrm{~mL})$. The residue was adsorbed on silica by co-evaporation and purified by silica column chromatography (elution with $2 \% \mathrm{MeOH} / \mathrm{DCM})$ affording the protected nucleoside 9 (1.70 g, $83 \%$ yield) as a white foam. ${ }^{1} \mathrm{H}-\mathrm{NMR}\left(500 \mathrm{MHz}, \mathrm{CDCl}_{3}\right): \delta 9.43(\mathrm{~s}, 1 \mathrm{H}, \mathrm{NH}), 8.78(\mathrm{~s}, 1 \mathrm{H}, 8-\mathrm{H}), 8.43$ (s, 1H, 2-H), 8.05 (d, J=7.5 Hz, 2H, H-Bz), 7.66-7.29 (m, 8H, Bz-H, Ar-H), 5.49 (s, 1H, Ph- $\underline{\mathrm{CH}}$ ), 5.22 (d, $\left.J=2.1 \mathrm{~Hz}, 1 \mathrm{H}, 1^{\prime}-\mathrm{H}\right), 5.09$ (s, 1H, 2'-H), 4.55 (td, $\left.J=10.0,5.3 \mathrm{~Hz}, 1 \mathrm{H}, 5{ }^{\prime}-\mathrm{H}\right), 4.44$ (dd, $J=10.4$, $\left.5.2 \mathrm{~Hz}, 1 \mathrm{H}, 6^{\prime}-\mathrm{He}\right), 3.88$ (brs, 1H, 3'-H), 3.85-3.76 (m, 2H, ,6'-Ha, 4'-H), 3.71 (s, 3H, OMe), 3.52 (s, 3H, OMe). ${ }^{13} \mathrm{C}-\mathrm{NMR}\left(125 \mathrm{MHz}, \mathrm{CDCl}_{3}\right): \delta 164.86(\mathrm{C}=\mathrm{O}) ; 152.77(\mathrm{C}-6) ; 152.06(\mathrm{C}-2) ; 149.78(\mathrm{C}-4) ; 141.06$ (C-8); 137.01, 133.35, 132.75, 129.09, 128.72, 128.19, 128.00, 126.11 (Ar-C, Bz-C); 122.75 (C-5); 102.43 (Ph-C); 99.19 (C-1'); 76.11 (C-5'); 76.08 (C-3'); 69.16 (C-4'); 59.98 (C-6'); 58.83 (OMe); 56.01 (OMe); 55.13 (C-2'). HRMS calcd. for $\mathrm{C}_{27} \mathrm{H}_{28} \mathrm{~N}_{5} \mathrm{O}_{6}{ }^{+}[\mathrm{M}+\mathrm{H}]^{+}$518.2034, found 518.2031. 
3.10. 4',6'-O-Benzylidene-1'-O-methyl-2'-deoxy-2'-(2-amino-6-(2-trimethylsilyl-ethoxy)purin-9-yl)-Daltropyranoside (11)

A mixture of $4.5 \mathrm{~g}(15.4 \mathrm{mmol})$ of 10 and $0.266 \mathrm{~g}(33.5 \mathrm{mmol})$ of lithium hydride in $60 \mathrm{~mL}$ of dry DMF was stirred under nitrogen at $90{ }^{\circ} \mathrm{C}$ for $2 \mathrm{~h}$. After addition of $2.6 \mathrm{~g}(9.8 \mathrm{mmol})$ of the epoxide 2 dissolved in $20 \mathrm{~mL}$ of dry DMF, stirring was continued for $18 \mathrm{~h}$ at $130{ }^{\circ} \mathrm{C}$. The reaction mixture was cooled and evaporated to dryness. The residue was dissolved in ethyl acetate $(100 \mathrm{~mL})$ and washed with brine $(100 \mathrm{~mL})$. A small part of the base precipitated during extraction and was filtered off and kept for recycling. The aqueous layer was again extracted with EtOAc $(3 \times 50 \mathrm{~mL})$. The combined organic layers were dried over $\mathrm{Na}_{2} \mathrm{SO}_{4}$, filtered, concentrated under vacuo, and purification by silica gel column chromatography (elution with 3\% MeOH in DCM) afforded $11(2.11 \mathrm{~g}, 42 \%)$ while recovering a large point of the starting $10(1.5 \mathrm{~g}, 26 \%) .{ }^{1} \mathrm{H}-\mathrm{NMR}\left(300 \mathrm{MHz}, \mathrm{CDCl}_{3}\right): \delta 8.03(\mathrm{~s}, 1 \mathrm{H}, 8-\mathrm{H}), 7.39(\mathrm{~m}, 5 \mathrm{H}$, Ar-H), 5.55 (s, 1H, Ph- $\underline{\mathrm{CH}}), 5.27$ (d, $\left.J=1.8 \mathrm{~Hz}, 1 \mathrm{H}, 1^{\prime}-\mathrm{H}\right), 5.04$ (s, 1H, 2'-H), 4.83-4.60 (m, 3H, - $\mathrm{NH}_{2}$, 5'-H), 4.59-4.38 (m, 3H, 6'-He, 6'-Ha, 3'-H), 4.36-4.29 (m, 1H, 4'-H), 3.89-3.73 (m, 2H, OCH2-), 3.55 (s, 3H, OMe), 1.21-1.10 (m, 9H, - $\left.\mathrm{SiC}_{3} \mathrm{H}_{9}\right) .{ }^{13} \mathrm{C}-\mathrm{NMR}\left(75 \mathrm{MHz}, \mathrm{CDCl}_{3}\right)$ : $\delta 161.74$ (C-6); 159.43 (C-2); 152.79 (C-4); 137.10 (C-8); 136.53 (Ar- $\mathrm{C}_{\mathrm{i}}$ ), 129.53 (Ar- $\mathrm{C}_{\mathrm{p}}$ ), 128.34 (Ar- $\mathrm{C}_{\mathrm{m}}$ ), 126.46 (Ar-Co); 115.06 (C-5); 102.58 (Ph- $\underline{\mathrm{C}}) ; 100.05$ (C-1'); 76.14 (C-4'); 69.25 (C-6'); 66.10 (C-5'); 65.09 (C-3'); 58.63 $\left(\underline{\mathrm{OCH}}_{2}-\right) ; 57.19(\mathrm{OMe}) ; 56.40\left(\mathrm{C}-2^{\prime}\right) ; 17.49\left(\underline{\mathrm{CH}_{2}} \mathrm{Si}\right) ;-1.46\left(-\mathrm{SiC}_{3} \underline{\mathrm{H}} 9\right)$.

\subsection{4',6'-O-Benzylidene-1',3'-di-O-methyl-2'-deoxy-2'-(2-amino-6-(2-trimethylsilylethoxy)-purin-9- yl)-D-altropyranoside (12)}

The obtained foam 11 (2.11 g, $4.1 \mathrm{mmol})$ was dried overnight under vacuum. The foam was dissolved in dry DMF (42 mL), cooled to $-30{ }^{\circ} \mathrm{C}$ and $\mathrm{NaH}(1.3 \mathrm{~g}, 32 \mathrm{mmol})$ was added and the mixture was stirred at $-30^{\circ} \mathrm{C}$ for $1 \mathrm{~h}$ under argon. Subsequently, methyl iodide $(1 \mathrm{~mL}, 16 \mathrm{mmol})$ was dissolved in dry DCM $(10.5 \mathrm{~mL})$ and the solution was added drop wise over $30 \mathrm{~min}$ to the reaction mixture at $-30{ }^{\circ} \mathrm{C}$ which was stirred further at $-30{ }^{\circ} \mathrm{C}$ for $1 \mathrm{~h}$. The reaction was finally running $3 \mathrm{~h}$ more at $-30{ }^{\circ} \mathrm{C}$ to $-20{ }^{\circ} \mathrm{C}$ before quenching with $10 \mathrm{~mL}$ of $\mathrm{MeOH}$ for $20 \mathrm{~min}$. The solution was concentrated and dissolved in DCM $(50 \mathrm{~mL})$ and washed with brine $(50 \mathrm{~mL})$. The aqueous layer was again extracted with DCM $(3 \times 50 \mathrm{~mL})$. The combined organic layers were dried over $\mathrm{Na}_{2} \mathrm{SO}_{4}$, filtered and concentrated under vacuo, and purification by silica gel column chromatography (elution with $2 \% \mathrm{MeOH}$ in DCM) afforded methylated nucleoside 12 (2.03 g, 94\%) as a white foam. ${ }^{1} \mathrm{H}-\mathrm{NMR}\left(500 \mathrm{MHz}, \mathrm{CDCl}_{3}\right): \delta 7.98(\mathrm{~s}, 1 \mathrm{H}$, 8-H), 7.49-7.40 (m, 1H, 2H, Ar-H), 7.38-7.30 (m, 3H, Ar-H), 5.47 (s, 1H, Ph-Cㅂ), 5.01 (s, 1H, 1'-H), 4.98-4.92 (m, 1H, 5'-H), 4.66-4.55 (m, 1H, 3'-H), 4.53-4.46 (m, 1H, 4'-H), 4.41 (dd, J= 10.4, 5.3 Hz, 1H, 6'-Ha), 1.26 (t, $J=12.1 \mathrm{~Hz}, 1 \mathrm{H}) .{ }^{13} \mathrm{C}-\mathrm{NMR}\left(126 \mathrm{MHz}, \mathrm{CDCl}_{3}\right): \delta 161.59(\mathrm{C}-6) ; 159.61(\mathrm{C}-2) ; 153.62$ (C-4); 137.21 (C-8); $136.93\left(\right.$ Ar- $\left.\mathrm{C}_{\mathrm{i}}\right) ; 129.07\left(\mathrm{Ar}-\mathrm{C}_{\mathrm{p}}\right) ; 128.21\left(\mathrm{Ar}-\mathrm{C}_{\mathrm{m}}\right) ; 126.16\left(\mathrm{Ar}-\mathrm{C}_{\mathrm{o}}\right) ; 115.15(\mathrm{C}-5)$; 102.42 (Ph- $\underline{\text { ) }}$; 99.45 (C-1'); 76.26 (C-4'); 76.06 (C-6'); 69.26 (C-5'); 65.04 (C-3'); 59.98 (OCH2-); 58.73 $(\mathrm{OMe}) ; 55.97(\mathrm{OMe}) ; 54.82\left(\mathrm{C}-2^{\prime}\right) ; 17.54\left(\mathrm{CH}_{2} \mathrm{Si}\right) ;-1.41$ (3C, Si(CH3)3). HRMS calcd. For $\mathrm{C}_{25} \mathrm{H}_{36} \mathrm{~N}_{5} \mathrm{O}_{6} \mathrm{Si}^{+}[\mathrm{M}+\mathrm{H}]^{+}$530.2429, found 530.2430. 


\subsection{4',6'-O-Benzylidene-1',3'-di-O-methyl-2'-deoxy-2'-(guanin-9-yl)-D-altropyranoside (13)}

A $1 \mathrm{M}$ solution of tetrabutylammonium fluoride in dry THF $(15.10 \mathrm{~mL})$ was added to the guanine derivative $12(2.0 \mathrm{~g}, 3.77 \mathrm{mmol})$ and the mixture was stirred at room temperature under $\mathrm{N}_{2}$ for $2 \mathrm{~h}$ after which water $(15 \mathrm{~mL})$ was added. The $\mathrm{pH}$ was adjusted to 5 with acetic acid and the mixture was evaporated. The residue was purified by silica gel column chromatography (elution with $10 \% \mathrm{MeOH}$ in DCM) affording 13 (1.25 g, 75\%). ${ }^{1} \mathrm{H}-\mathrm{NMR}\left(500 \mathrm{MHz}, \mathrm{CDCl}_{3}\right)$ : $\delta 11.99$ (s, 1H, $\left.\underline{\mathrm{NH}}\right), 7.86(\mathrm{~s}, 1 \mathrm{H}, 8-\mathrm{H})$, $7.42(\mathrm{~m}, 2 \mathrm{H}, \mathrm{Ar}-\mathrm{H}), 7.31$ (m, 3H, Ar-H), 6.73 (s, H, 2H, 2-NH2), 5.49 (s, 1H, Ph- $\underline{\mathrm{CH}}), 5.07$ (s, 1H, 1'-H), 4.81 (s, 1H, 2'-H), 4.50-4.42 (m, 1H, 5'-H), 4.37 (dd, $J=10.1,5.0 \mathrm{~Hz}, 1 \mathrm{H}, 6$ '-He), 3.78 (s, 3H, 3'-H, 6-Ha, 4'-H), 3.58 (s, 3H, OMe), 3.53 (s, 3H, OMe). ${ }^{13} \mathrm{C}-\mathrm{NMR}\left(125 \mathrm{MHz}, \mathrm{CDCl}_{3}\right)$ : $\delta 159.03$ (C-6);

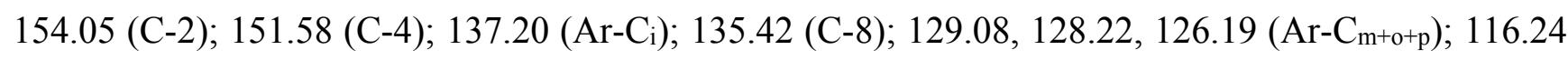
(C-5); 102.40 (Ph-C); 99.23 (C-1'); 76.11 (C-4'); 76.04 (C-6'); 69.19 (C-5'); 59.76 (C-4'); 58.68 (OMe); 55.98 (OMe); 54.79 (C-2'). HRMS calcd. For $\mathrm{C}_{20} \mathrm{H}_{24} \mathrm{~N}_{5} \mathrm{O}_{6}{ }^{+}[\mathrm{M}+\mathrm{H}]^{+} 430.1721$, found 430.1711 .

\subsection{4',6'-O-Benzylidene-1',3'-di-O-methyl-2'-deoxy-2'-(N²-(dimethylamino)methylene-guanin-9-yl))- D-altropyranoside (14)}

An amount of $13(0.66 \mathrm{~g}, 1.54 \mathrm{mmol})$ was co evaporated three times with pyridine, dissolved in $30 \mathrm{~mL}$ of dry $\mathrm{MeOH}(20 \mathrm{~mL})$ and $N, N$-dimethylformamide diethyl acetal $(0.824 \mathrm{~mL}, 6.16 \mathrm{mmol})$ was added. The mixture was stirred at reflux for $2 \mathrm{~h}$ under argon, after which it was evaporated and co-evaporated with toluene $(3 \times 30 \mathrm{~mL})$. The residue was purified by silica gel column chromatography (2\%-5\% MeOH/dichloromethane) affording the analog 14 (0.634 g, 85\%). ${ }^{1} \mathrm{H}-\mathrm{NMR}\left(500 \mathrm{MHz}, \mathrm{CDCl}_{3}\right)$ : $\delta 9.78\left(\mathrm{~s}, 1 \mathrm{H}, \mathrm{N}^{1}-\mathrm{H}\right), 8.65(\mathrm{~s}, 1 \mathrm{H}, \mathrm{N}=\underline{\mathrm{CH}}-\mathrm{N}), 7.97(\mathrm{~s}, 1 \mathrm{H}, 8-\mathrm{H}), 7.45(\mathrm{~m}, 2 \mathrm{H}, \mathrm{Ar}-\mathrm{H}), 7.40-7.30$ (m, 3H, Ar-H), 5.51 (s, 1H, Ph- $\underline{\mathrm{CH}}$ ), 5.02 (s, 1H, 2'-H), 4.99 (d, J=2.2 Hz, 1H, 1'-H), 4.50 (td, $J=10.4,5.3 \mathrm{~Hz}$, 1H, 5'-H), 4.41 (dd, J=10.4, 5.3 Hz, 1H, 6-He), 3.90-3.80 (m, 3H, 3'-H, 6-Ha, 4'-H), 3.68 (s, 3H, OMe), $3.50(\mathrm{~s}, 3 \mathrm{H}, \mathrm{OMe}), 3.18(\mathrm{~s}, 3 \mathrm{H}, \mathrm{NMe}), 3.15$ (s, 3H, NMe). ${ }^{13} \mathrm{C}-\mathrm{NMR}\left(125 \mathrm{MHz}, \mathrm{CDCl}_{3}\right): \delta 158.12$ $(\mathrm{N}=\underline{\mathrm{CH}}-\mathrm{N}) ; 157.97$ (C-6); 157.04 (C-2); 150.18 (C-4); 137.20 (C-8); 136.08, 129.05, 128.19, 126.14 (Ar-C); 119.85 (C-4); 102.39 (Ph- $\underline{\mathrm{CH}}$ ); 99.31 (C-1'); 76.47 (C-4'); 76.12 (C-6'); 69.17 (C-3'); 60.14 (C-5'); 58.67 (OMe); 55.89 (OMe); 55.13 (C-2'); 41.44 (NMe); 35.23 (NMe). HRMS calcd. for $\mathrm{C}_{23} \mathrm{H}_{29} \mathrm{~N}_{6} \mathrm{O}_{6}{ }^{+}[\mathrm{M}+\mathrm{H}]^{+}$485.2143, found 485.2145.

\subsection{1',3'-Di-O-methyl-2'-deoxy-2'-(uracil-1-yl)-D-altropyranoside (15a)}

Compound 4 (0.9 g, $2.31 \mathrm{mmol})$ was dissolved in $60 \mathrm{~mL}$ of $\mathrm{AcOH}-\mathrm{H}_{2} \mathrm{O}$ (3:1) at rt. The reaction mixture was slowly heated at $45{ }^{\circ} \mathrm{C}$ and reaction progress was monitored using TLC. After $12 \mathrm{~h}$, the mixture was concentrated and co evaporated with toluene $(30 \mathrm{~mL})$. The crude residue was purification by flash silica gel column chromatography (elution with 5\% $\mathrm{MeOH}$ in DCM) afforded compound 15a (0.66 g, 94\%). ${ }^{1} \mathrm{H}-\mathrm{NMR}\left(600 \mathrm{MHz}, \mathrm{DMSO}-d_{6}\right): \delta 11.15$ (s, 1H, NH), $7.71(\mathrm{~s}, 1 \mathrm{H}, 6-\mathrm{H}), 5.56$ (d, J= 5.5 Hz, $1 \mathrm{H}, 5-\mathrm{H}), 4.93$ (d, $\left.J=3.9 \mathrm{~Hz}, 1 \mathrm{H}, 1^{\prime}-\mathrm{H}\right), 4.88$ (t, $\left.J=5.0 \mathrm{~Hz}, 1 \mathrm{H}, 2^{\prime}-\mathrm{H}\right), 4.84-4.60$ (m, 1H, 3'-H), 4.03 (dd, $J=9.8,5.5 \mathrm{~Hz}, 1 \mathrm{H}, 5 '-\mathrm{H}), 3.77$ (q, $\left.J=5.5 \mathrm{~Hz}, 1 \mathrm{H}, 4^{\prime}-\mathrm{H}\right), 3.65-3.53$ (m, 2H, 6'-H), 3.26, (s, 3H, $\mathrm{OMe}), 3.22$ (s, 3H, OMe). ${ }^{13} \mathrm{C}-\mathrm{NMR}\left(150 \mathrm{MHz}, \mathrm{DMSO}-d_{6}\right): \delta 170.83$ (C-4); 163.61 (C-2); 151.66 (C-6); 101.62 (C-5); 99.07 (C-1'); 77.52 (C-5'); 76.08 (C-3); 63.67 (C-4'); 61.12 (C-6'); 60.23 (OMe); 56.65 (OMe); 55.39 (C-2'). HRMS calcd. For $\mathrm{C}_{12} \mathrm{H}_{19} \mathrm{~N}_{2} \mathrm{O}_{7}{ }^{+}[\mathrm{M}+\mathrm{H}]^{+} 325.1006$, found 325.1005 . 


\subsection{1',3'-Di-O-methyl-2'-deoxy-2'-(N'-benzoylcytosin-1-yl)-D-altropyranoside (15b)}

Compound 6 (0.36 g, $0.73 \mathrm{mmol})$ was dissolved in $24.1 \mathrm{~mL}$ of $\mathrm{AcOH}: \mathrm{H}_{2} \mathrm{O}(3: 1)$ at rt. The reaction mixture was slowly heated at $45^{\circ} \mathrm{C}$ and further treated as per the synthesis of $\mathbf{1 5 a}$ affording the nucleoside analog 15b (0.28 g, 50\%). ${ }^{1} \mathrm{H}-\mathrm{NMR}\left(300 \mathrm{MHz}, \mathrm{CD}_{3} \mathrm{OD}\right): 8.23-7.94$ (m, 3H, 6-H, Bz-H), 7.68-7.51 (m, $4 \mathrm{H}, 5-\mathrm{H}, \mathrm{Bz}-\mathrm{H}), 5.26$ (brs, 1H, 1'-H), 4.87-4.81 (m, 1H, 2'-H), 4.23-4.09 (m, 1H, 5'-H), 4.03 (q, 1H, $\left.J=5.5 \mathrm{~Hz}, 4^{\prime}-\mathrm{H}\right), 3.80-3.66$ (m, 2H, 3'-H, 6'-He), 3.30 (s, 6H, 2OMe), 3.26-3.20 (m, 1H, 6'-Ha). ${ }^{13} \mathrm{C}-\mathrm{NMR}$ (150 MHz, CD $\left.3 \mathrm{OD}\right): 169.07$ (PhCONH), 164.69 (C-4), 158.61 (C-2), 134.65 (C-6), 134.13, 130.47, 129.84, 129.59, 129.19 (Bz-C), 100.35 (C-5), 98.59 (C-1'), 64.94 (C-3'), 64.74 (C-5'), 63.46 (C-4'), $62.47\left(\mathrm{C}^{\prime} 6^{\prime}\right), 57.75(\mathrm{OMe}), 56.05(\mathrm{OMe}), 49.85\left(\mathrm{C}-2^{\prime}\right)$. HRMS calcd. for $\mathrm{C}_{19} \mathrm{H}_{24} \mathrm{~N}_{3} \mathrm{O}_{7}{ }^{+}[\mathrm{M}+\mathrm{H}]^{+}$ 406.1609, found 406.1608 .

\subsection{1',3'-Di-O-methyl-2'-deoxy-2'-(N6-benzoyladenin-9-yl)-D-altropyranoside (15c)}

Following the procedure for 15a, compound 9 (1.65 g, $3.19 \mathrm{mmol})$ was treated $82.85 \mathrm{~mL}$ of AcOH: $\mathrm{H}_{2} \mathrm{O}(3: 1)$ at $\mathrm{rt}$. The reaction mixture was slowly heated at $45{ }^{\circ} \mathrm{C}$ and reaction progress was monitored using TLC. After $12 \mathrm{~h}$, the mixture was concentrated and co evaporated with toluene, and after purification afforded $(0.78 \mathrm{~g}, 57 \%)$ of $\mathbf{1 5 c}$.

${ }^{1} \mathrm{H}-\mathrm{NMR}\left(300 \mathrm{MHz}, \mathrm{CD}_{3} \mathrm{OD}\right): \delta 8.76(\mathrm{~s}, 1 \mathrm{H}, 8-\mathrm{H}), 8.52(\mathrm{~s}, 1 \mathrm{H}, 2-\mathrm{H}), 8.13(\mathrm{~d}, J=7.4 \mathrm{~Hz}, 2 \mathrm{H}, \mathrm{Bz}-\mathrm{H})$, $7.77-7.53(\mathrm{~m}, 3 \mathrm{H}, \mathrm{Bz}-\mathrm{H}), 5.39$ (d, $\left.J=5.5 \mathrm{~Hz}, 1 \mathrm{H}, 1^{\prime}-\mathrm{H}\right), 4.88-4.82\left(\mathrm{~m}, 1 \mathrm{H}, 22^{\prime}-\mathrm{H}\right), 4.31$ (dd, $J=8.8$, $\left.3.7 \mathrm{~Hz}, 1 \mathrm{H}, 5^{\prime}-\mathrm{H}\right), 4.26-4.21$ (m, 1H, 3'-H), 4.13 (q, $\left.J=5.5 \mathrm{~Hz}, 1 \mathrm{H}, 4^{\prime}-\mathrm{H}\right), 4.00-3.9$ (m, 2H, 6'-H), 3.42 (s, 3H, OMe), 3.36 (s, 3H, OMe). ${ }^{13} \mathrm{C}-\mathrm{NMR}$ (75 MHz, DMSO-d6): $\delta 165.20(\mathrm{C}=\mathrm{O}) ; 152.25(\mathrm{C}-6) ; 150.77$ (C-2); 149.68 (C-4); 143.85 (C-8); 132.92 (C-5); 131.89, 127.95, 127.91, 125.07 (Bz-C); 97.91 (C-1'); 77.10 (C-5'); 75.44 (C-3'); 62.37 (C-4'); 59.78 (C-6'); 55.75 (OMe); 55.53 (OMe); 54.53 (C-2'). HRMS calcd. for $\mathrm{C}_{20} \mathrm{H}_{24} \mathrm{~N}_{5} \mathrm{O}_{6}{ }^{+}[\mathrm{M}+\mathrm{H}]^{+} 430.1721$, found 430.1716 .

3.17. 1',3'-Di-O-methyl-2'-deoxy-2'-(N²-(dimethylamino)methylene-guanin-9-yl))-D-altro-pyranoside (15d)

Compound $14(0.58 \mathrm{~g}, 1.2 \mathrm{mmol})$ was dissolved in $30 \mathrm{~mL}$ of $\mathrm{AcOH}: \mathrm{H}_{2} \mathrm{O}$ (3:1) at rt. The reaction mixture was slowly heated at $45{ }^{\circ} \mathrm{C}$ and reaction progress was monitored using TLC. After $12 \mathrm{~h}$, the mixture was concentrated and co-evaporated with toluene. The crude residue was purified by flash silica gel column chromatography (elution with $10 \% \mathrm{MeOH}$ in DCM) afforded compound $\mathbf{1 5 d}(0.4 \mathrm{~g}, 81 \%)$. ${ }^{1} \mathrm{H}-\mathrm{NMR}\left(500 \mathrm{MHz}, \mathrm{CD}_{3} \mathrm{OD}\right): \delta 8.65(\mathrm{~s}, 1 \mathrm{H}, \mathrm{N}=\underline{\mathrm{CH}}-\mathrm{N}), 7.85(\mathrm{~s}, 1 \mathrm{H}, 8-\mathrm{H}), 5.21(\mathrm{~d}, J=5.3 \mathrm{~Hz}, 1 \mathrm{H}$, 2'-H), 4.64-4.57 (m, 1H, 1'-H), 4.10 (m, 2H, 4'-H, 3'-H), 4.00 (dd, J = 8.8, 4.1 Hz, 1H, 5'-H), 3.84 (d, $\left.J=4.6 \mathrm{~Hz}, 2 \mathrm{H}, 66^{\prime}-\mathrm{H}\right), 3.33$ (s, 3H, OMe), 3.30 (s, 3H, OMe), 3.16 (s, 3H, OMe), 3.07 (s, 3H, OMe). ${ }^{13} \mathrm{C}-\mathrm{NMR}\left(125 \mathrm{MHz}, \mathrm{CD}_{3} \mathrm{OD}\right): \delta 160.31(\mathrm{~N}=\underline{\mathrm{C}}-\mathrm{N}) ; 159.83$ (C-6); 158.79 (C-2); 152.31 (C-4); 140.37 (C-8); 120.48 (C-5); 100.37 (C-1'); 78.41 (C-5'); 76.47 (C-3'); 65.24 (C-4'); 62.66 (C-6'); 57.94 (OMe); $57.74(\mathrm{OMe}) ; 56.17\left(\mathrm{C}-2^{\prime}\right) ; 41.53$ and $35.34\left(\mathrm{NMe}_{2}\right)$. HRMS calcd. for $\mathrm{C}_{16} \mathrm{H}_{25} \mathrm{~N}_{6} \mathrm{O}_{6}{ }^{+}[\mathrm{M}+\mathrm{H}]^{+} 397.1830$, found 397.1827 .

\subsection{6'-O-Dimethoxytrityl-1',3'-di-O-methyl-2'-deoxy-2'-(uracil-1-yl)-D-altropyranoside (16a)}

To a solution of the nucleoside 15a $(0.4 \mathrm{~g}, 1.32 \mathrm{mmol})$ in anhydrous pyridine $(10 \mathrm{~mL})$ and under argon atmosphere, dimethoxytrityl chloride $(0.49 \mathrm{~g}, 1.45 \mathrm{mmol})$ was added under stirring on an ice bath. 
After stirring at room temperature for $3 \mathrm{~h}, 5 \%$ aqueous $\mathrm{NaHCO}_{3}$ solution $(1 \mathrm{~mL})$ was added, the reaction solvent was evaporated, diluted with $\mathrm{CH}_{2} \mathrm{Cl}_{2}(50 \mathrm{~mL})$ and washed with $5 \%$ aqueous $\mathrm{NaHCO}_{3}(2 \times 30 \mathrm{~mL})$. The aqueous layers were back extracted once with $30 \mathrm{~mL} \mathrm{CH}_{2} \mathrm{Cl}_{2}$. The combined organic layer was dried $\left(\mathrm{Na}_{2} \mathrm{SO}_{4}\right)$, evaporated under reduced pressure and the crude residue was purified by flash chromatography $\left(\mathrm{CH}_{2} \mathrm{Cl}_{2} / \mathrm{MeOH} 96: 4\right)$ affording the corresponding dimethoxytritylated nucleoside 16a $\left(0.745 \mathrm{~g}, 93 \%\right.$ yield) as a white foam. ${ }^{1} \mathrm{H}-\mathrm{NMR}\left(125 \mathrm{MHz}, \mathrm{CDCl}_{3}\right): \delta 9.31$ (brs, $\left.1 \mathrm{H}, \mathrm{NH}\right), 7.48-7.43$ (m, 2H, 6-H, Ar-H), 7.37-7.33 (m, 4H, Ar-H), 7.31-7.26 (m, 2H, Ar-H), 7.24-7.19 (m, 1H, Ar-H), 6.85-6.82 (m, 4H, Ar-H), 5.69 (dd, $J=8.0,1.6$ Hz, 1H, 5-H), 5.30 (brs, 1H, 1'-H), 4.94 (brs, 1H, 2'-H), 4.08-3.95 (m, 2H, 5'-H, 3'-H), 3.79 (s, 3H, OMe), 3.78-3.77 (m, 4H, OMe, 4'-H), 3.50-3.42 (brs, s, 6H, 2OMe), 3.42-3.40 (m, 2H, 6'-H). ${ }^{13} \mathrm{C}-\mathrm{NMR}\left(125 \mathrm{MHz}, \mathrm{CDCl}_{3}\right)$ : $\delta 163.28$ (C-4); 158.50 (C-2); 150.68 (C-6); 144.85, 135.84, 130.09, 130.06, 128.10, 127.80, 126.81, 113.11 (Ar-C); 102.35 (C-5); 98.36 (C-1'); $86.20\left(\mathrm{C}^{\mathrm{Tr}}-\mathrm{O}\right)$; 77.14 (C-5'), 76.87 (C-3'); 64.05 (C-4'); 62.88 (C-6'); 57.93 (OMe); 55.69 (OMe); 55.19 (2OMe, C-2'). HRMS calcd. for $\mathrm{C}_{33} \mathrm{H}_{36} \mathrm{~N}_{2} \mathrm{O}_{9} \mathrm{Na}^{+}[\mathrm{M}+\mathrm{Na}]^{+}$627.23186, found 627.2311.

\subsection{6'-O-Dimethoxytrityl-1',3'-di-O-methyl-2'-deoxy-2'-(N6-benzoylcytosin-1-yl)-D-altropyranoside (16b)}

Compound 16b (0.346 g, 87\% yield) was synthesized from compound $15 \mathbf{b}(0.228 \mathrm{~g}, 0.56 \mathrm{mmol})$ using dimethoxytrityl chloride $(0.09 \mathrm{~g}, 1.29 \mathrm{mmol})$ in anhydrous pyridine $(10 \mathrm{~mL})$ according to the procedure used for the synthesis of compound 16a. ${ }^{1} \mathrm{H}-\mathrm{NMR}\left(500 \mathrm{MHz}, \mathrm{CDCl}_{3}\right): \delta 8.75$ (brs, $\left.1 \mathrm{H}, \mathrm{NH}\right)$, 7.90 (d, $J=7.3 \mathrm{~Hz}, 2 \mathrm{H}, 6-\mathrm{H}, \mathrm{Ar}-\mathrm{H}), 7.64-7.45$ (m, 6H, Ar-H), 7.40-7.19 (m, 8H, 5-H, Ar-H), 6.86 (d, $J=8.8 \mathrm{~Hz}, 4 \mathrm{H}, \mathrm{Ar}-\mathrm{H}), 5.29$ (s, 1H, 1'-H), 5.03 (brs, 1H, 2'-H), 4.11-3.95 (m, 2H, 5'-H, 3'-H), 3.83-3.77 (m, 7H, 2OMe, 4'-H), 3.60-3.37 (m, 8H, 6'-H, 2OMe), 2.50 (s, 1H, 4-OH). ${ }^{13} \mathrm{C}-\mathrm{NMR}$ (126 MHz, $\left.\mathrm{CDCl}_{3}\right): \delta 166.13(\mathrm{C}=0), 162.13$ (C-4), 158.47 (C-4), 144.71 (C-6), 136.02, 133.17, 130.03, 129.01, 128.20, 127.79, 127.50, 126.80, 113.10 (Ar-C), 98.06 (C-5), $96.85\left(\mathrm{C}-1^{\prime}\right), 86.11\left(\mathrm{C}^{\mathrm{Tr}}-\mathrm{O}\right), 77.13$ (C-5'), 76.88 (C-3'), 65.62 (C-4'), 62.73 (C-6'), 58.04 (OMe), 55.72 (OMe), 55.18 (C-2, 2OMe). HRMS calcd. For $\mathrm{C}_{40} \mathrm{H}_{42} \mathrm{~N}_{3} \mathrm{O}_{9}^{+}[\mathrm{M}+\mathrm{H}]^{+}$708.29208, found 708.2909.

\subsection{6'-O-Dimethoxytrityl-1',3'-di-O-methyl-2'-deoxy-2'-(N'-benzoyladenin-9-yl)-D-altropyranoside (16c)}

Compound 16c (0.77 g, 91\% yield) was synthesized from compound $15 \mathrm{c}(0.5 \mathrm{~g}, 1.16 \mathrm{mmol})$ using dimethoxytrityl chloride $(0.44 \mathrm{~g}, 1.27 \mathrm{mmol})$ in anhydrous pyridine $(10 \mathrm{~mL})$ according to the procedure used for the synthesis of compound 16a. ${ }^{1} \mathrm{H}-\mathrm{NMR}\left(500 \mathrm{MHz}, \mathrm{CDCl}_{3}\right)$ : $\delta 9.15$ (brs, $\left.1 \mathrm{H}, 2-\mathrm{H}\right), 8.12$ (s, 1H, 8-H), 8.03 (d, $J=8.0 \mathrm{~Hz}, 2 \mathrm{H}, \mathrm{Ar}-\mathrm{H}), 7.60$ (t, $J=7.4 \mathrm{~Hz}, 1 \mathrm{H}, \mathrm{Ar}-\mathrm{H}), 7.52-7.49$ (m, 3H, Ar-H), 7.40 $(\mathrm{d}, J=8.8 \mathrm{~Hz}, 4 \mathrm{H}, \mathrm{Ar}-\mathrm{H}), 7.34-7.21$ (m, 5H, Ar-H), 6.85 (d, $J=8.8 \mathrm{~Hz}, 3 \mathrm{H}, \mathrm{Ar}-\mathrm{H}), 5.29(\mathrm{t}, J=1.1 \mathrm{~Hz}$, $\left.1 \mathrm{H}, 1^{\prime}-\mathrm{H}\right), 5.20\left(\mathrm{~d}, J=4.8 \mathrm{~Hz}, 1 \mathrm{H}, 2^{\prime}-\mathrm{H}\right), 4.79-4.68\left(\mathrm{~m}, 1 \mathrm{H}, 6^{\prime}-\mathrm{He}\right), 4.27$ (q, $\left.J=5.5 \mathrm{~Hz}, 1 \mathrm{H}, 5^{\prime}-\mathrm{H}\right), 4.18$ (dd, $\left.J=7.9,3.8 \mathrm{~Hz}, 1 \mathrm{H}, 4{ }^{\prime}-\mathrm{H}\right), 4.07$ (t, $J=4.7 \mathrm{~Hz}, 1 \mathrm{H}, 3$ '-H), 3.79 (s, 6H, OMe), $3.53-3.47$ (m, 2H, 6'-Ha, OH), 3.41 (s, 3H, OMe), 3.29 (s, 3H, OMe). ${ }^{13} \mathrm{C}-\mathrm{NMR}\left(125 \mathrm{MHz}, \mathrm{CDCl}_{3}\right): \delta 164.63(\mathrm{C}-6) ; 158.52$ (Ar-C); 152.46 (C-2); 151.78 (C-4); 149.56 (C-8); 144.66, 143.58, 135.84, 133.67, 132.75, 130.05, 128.84, 128.17, 127.85, 126.84, 123.11, 113.16 (Ar-C); 98.31 (C-1'); $86.33\left(\mathrm{C}^{\mathrm{Tr}}-\mathrm{O}\right) ; 76.26\left(\mathrm{C}-5^{\prime}\right) ; 72.89$ (C-3'); 64.68 (C-4'); 62.90 (C-6'); 57.89 (OMe); 56.87 (OMe); 55.94 (OMe); 55.19 (OMe); 53.38 (C-2'). HRMS calcd. for $\mathrm{C}_{41} \mathrm{H}_{42} \mathrm{~N}_{5} \mathrm{O}_{8}{ }^{+}[\mathrm{M}+\mathrm{H}]^{+} 732.30332$, found 732.3030 . 
3.21. 6'-O-Dimethoxytrityl-1',3'-di-O-methyl-2'-deoxy-2'-(N²-(dimethylamino)methylene-guanin-9-yl))D-altropyranoside (16d)

Compound 16d ( $0.51 \mathrm{~g}, 74 \%$ yield $)$ was synthesized from compound $15 \mathbf{d}(0.39 \mathrm{~g}, 0.974 \mathrm{mmol})$ using dimethoxytrityl chloride $(0.362 \mathrm{~g}, 1.07 \mathrm{mmol})$ in anhydrous pyridine $(10 \mathrm{~mL})$ according to the procedure used for the synthesis of compound 16a. ${ }^{1} \mathrm{H}-\mathrm{NMR}\left(500 \mathrm{MHz}, \mathrm{CDCl}_{3}\right): \delta 9.20(\mathrm{~s}, 1 \mathrm{H}, \mathrm{NH}), 8.61(\mathrm{~d}$, $J=4.2 \mathrm{~Hz}, 1 \mathrm{H}, \mathrm{N}=\underline{\mathrm{CH}}-\mathrm{N}), 8.52(\mathrm{~s}, 1 \mathrm{H}, 8-\mathrm{H}), 7.79(\mathrm{~s}, 1 \mathrm{H}, \mathrm{Ar}-\mathrm{H}), 7.68(\mathrm{tt}, J=7.7,1.8 \mathrm{~Hz}, 1 \mathrm{H}, \operatorname{Ar}-\mathrm{H})$, 7.52-7.48 (m, 2H, Ar-H), 7.41-7.36 (m, 4H, Ar-H), 7.33-7.20 (m, 5H, Ar-H), 6.87-6.82 (m, 4H, Ar-H), 5.29 (s, 1H, 1'-H), 5.09 (d, $\left.J=3.1 \mathrm{~Hz}, 1 \mathrm{H}, 2^{\prime}-\mathrm{H}\right), 4.79$ (dd, $\left.J=6.4,3.1 \mathrm{~Hz}, 1 \mathrm{H}, 3^{\prime}-\mathrm{H}\right), 4.17-4.11$ (m, 1H, 5'-H), 4.01 (brs, 1H, -OH), 3.88 (dd, $\left.J=6.4,4.0 \mathrm{~Hz}, 1 \mathrm{H}, 4^{\prime}-\mathrm{H}\right), 3.52$ (dd, $J=10.2,2.9 \mathrm{~Hz}, 1 \mathrm{H}$, 6-He), 3.46 (s, 3H, OMe), 3.44 (s, 3H, OMe), 3.35 (dd, $J=10.2,5.5 \mathrm{~Hz}, 1 \mathrm{H}, 6$ '-Ha), 3.05 (s, 3H, OMe), $2.93(\mathrm{~s}, 3 \mathrm{H}, \mathrm{OMe}) .{ }^{13} \mathrm{C}-\mathrm{NMR}\left(125 \mathrm{MHz}, \mathrm{CDCl}_{3}\right): \delta 158.50$ (N=ㅡ- $\left.\mathrm{N}\right) ; 157.92$ (MMTr); 157.78 (C-6); 156.55(C-2); 150.39(C-4); 149.81 (C-8); 144.84 (Ar-C), 137.33, 135.98, 135.87, 130.06, 130.02, 128.10,

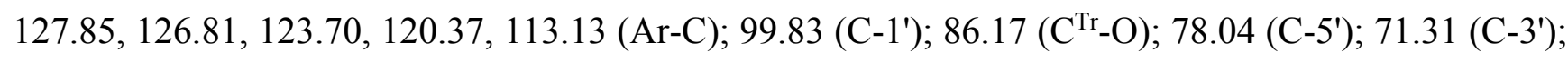
64.79 (C-4'); 63.87 (C-6'); 58.37 (OMe); 55.65 (OMe); 54.56 (C-2'); 41.12 and 35.12 (-NMe $)$. HRMS calcd. for $\mathrm{C}_{37} \mathrm{H}_{43} \mathrm{~N}_{6} \mathrm{O}_{8}{ }^{+}[\mathrm{M}+\mathrm{H}]^{+}$699.3142, found 699.3121 .

\subsection{General Procedure for Nucleoside Phosphitylation}

To a solution of the dimethoxytritylated nucleoside $16 \mathbf{a}(0.73 \mathrm{~g}, 1.2 \mathrm{mmol})$ in anhydrous $\mathrm{CH}_{2} \mathrm{Cl}_{2}$ $(6 \mathrm{~mL})$ at $0{ }^{\circ} \mathrm{C}$ and under argon atmosphere, freshly dried diisopropylethylamine $(0.063 \mathrm{~mL}, 3.6 \mathrm{mmol})$ and 2-cyanoethyl- $N, N$-diisopropylchlorophosphoramidite $(0.040 \mathrm{~mL}, 1.8 \mathrm{mmol})$ were added. The reaction mixture was stirred at $0{ }^{\circ} \mathrm{C}$ for $90 \mathrm{~min}$ after which completeness of the reaction was indicated by TLC. Saturated $\mathrm{NaHCO}_{3}$ solution $(2 \mathrm{~mL})$ was added, the solution was stirred for another 10 min and partitioned between $\mathrm{CH}_{2} \mathrm{Cl}_{2}(50 \mathrm{~mL})$ and aqueous $\mathrm{NaHCO}_{3}(30 \mathrm{~mL})$. The organic layer was washed with brine $(3 \times 30 \mathrm{~mL})$ and the aqueous phases were back extracted with $\mathrm{CH}_{2} \mathrm{Cl}_{2}(30 \mathrm{~mL})$. After solvent evaporation, the resulting oil was purified by flash chromatography (hexane/acetone/TEA $=62 / 36 / 2$ ). The yellow solid was then dissolved in $\mathrm{CH}_{2} \mathrm{Cl}_{2}(2 \mathrm{~mL})$ and precipitated twice in cold hexane $(160 \mathrm{~mL}$, $\left.-30{ }^{\circ} \mathrm{C}\right)$ to afford the desired corresponding phosphoramidite nucleoside $\mathbf{1 7 a}(0.908 \mathrm{~g}, 93 \%$ yield $)$ as a white powder. The obtained product was dried under vacuum and stored overnight under argon at $-20{ }^{\circ} \mathrm{C} .{ }^{31} \mathrm{P}-\mathrm{NMR}\left(\mathrm{CDCl}_{3}\right): \delta=150.84$. HRMS calcd. for $\mathrm{C}_{42} \mathrm{H}_{54} \mathrm{~N}_{4} \mathrm{O}_{10} \mathrm{P}_{1}{ }^{+}[\mathrm{M}+\mathrm{H}]^{+} 805.35773$, found 805.3557; ${ }^{31} \mathrm{P}-\mathrm{NMR}\left(\mathrm{CDCl}_{3}\right): \delta=150.84$.

Compound $\mathbf{1 7 b}$ ( $0.34 \mathrm{~g}, 79 \%$ yield) was synthesized from compound $\mathbf{1 6 b}(0.34 \mathrm{~g}, 0.47 \mathrm{mmol})$, dry diisopropylethylamine $(0.025 \mathrm{~mL}, 1.42 \mathrm{mmol}), 2$-cyanoethyl- $N, N$-diisopropylchloro-phosphoramidite $(0.016 \mathrm{~mL}, 0.71 \mathrm{mmol})$ and anhydrous $\mathrm{CH}_{2} \mathrm{Cl}_{2}(10 \mathrm{~mL})$ according to procedure used for the synthesis of compound 17a. ${ }^{31} \mathrm{P}-\mathrm{NMR}\left(\mathrm{CDCl}_{3}\right): \delta=150.96$. HRMS calcd. for $\mathrm{C}_{49} \mathrm{H}_{59} \mathrm{~N}_{5} \mathrm{O}_{10} \mathrm{P}_{1}[\mathrm{M}+\mathrm{H}]^{+} 908.39993$, found 908.3981 .

Compound 17c (0.83 g, 85\% yield) was synthesized from compound 16c (0.76 g, $1.03 \mathrm{mmol})$, dry diisopropylethylamine $(0.054 \mathrm{~mL}, 3.09 \mathrm{mmol})$, 2-cyanoethyl- $N, N$-diisopropylchloro-phosphoramidite $(0.034 \mathrm{~mL}, 1.54 \mathrm{mmol})$ and anhydrous $\mathrm{CH}_{2} \mathrm{Cl}_{2}(10 \mathrm{~mL})$ according to procedure used for the synthesis of compound 17a. ${ }^{31} \mathrm{P}-\mathrm{NMR}\left(\mathrm{CDCl}_{3}\right): \delta=150.287$ and 151.231 . HRMS calcd. for $\mathrm{C}_{50} \mathrm{H}_{59} \mathrm{~N}_{7} \mathrm{O}_{9} \mathrm{P}_{1}{ }^{+}[\mathrm{M}+\mathrm{H}]^{+}$ 932.41116, found 932.4103 . 
Compound 17d (0.42 g, 65\% yield) was synthesized from compound 16d ( $0.5 \mathrm{~g}, 0.71 \mathrm{mmol})$, dry diisopropylethylamine $(0.037 \mathrm{~mL}, 2.13 \mathrm{mmol}), 2$-cyanoethyl- $N, N$-diisopropylchloro-phosphoramidite $(0.025 \mathrm{~mL}, 1.15 \mathrm{mmol})$ and anhydrous $\mathrm{CH}_{2} \mathrm{Cl}_{2}(10 \mathrm{~mL})$ according to procedure used for the synthesis of compound 17a. ${ }^{31} \mathrm{P}-\mathrm{NMR}\left(\mathrm{CDCl}_{3}\right): \delta=150.065$ and 151.206 . HRMS calcd. for $\mathrm{C}_{46} \mathrm{H}_{60} \mathrm{~N}_{8} \mathrm{O}_{9} \mathrm{P}_{1}{ }^{+}[\mathrm{M}+\mathrm{H}]^{+}$ 899.42206, found 899.4240 .

\section{Conclusions}

A new nucleoside analogue scaffold for incorporation into oligonucleotides was developed and all four monomers with the natural heterocyclic bases have been prepared and evaluated on their hybridization potential with natural DNA and RNA. While it was anticipated that the constraint imposed by the 6-membered ring structure could afford the entropic advantage as seen with HNA and ANA constructs, an entropic penalty to preserve the ${ }^{1} \mathrm{C}_{4}$ conformation required for pairing with RNA annulated the affinity gain which one could expect from a pre-organized structure.

\section{Acknowledgments}

This work was supported by a FWO (Flemish Scientific Research) grant G.0784.11 and KU Leuven financial support (GOA/10/13). Mass spectrometry was made possible by the support of the Hercules Foundation of the Flemish Government (grant 20100225-7). We are indebted to Chantal Biernaux for final typesetting.

\section{Author Contributions}

A.V. and D.K. synthesized and analyzed the different monomers; G.S. assembled oligonucleotides and carried out Tm analysis; J.R. carried out all mass spectrometric analysis; M.F. performed the modeling experiments; A.V.A. conceived and supervised research and wrote the paper.

\section{Conflicts of Interest}

The authors declare no conflict of interest.

\section{References}

1. Helene, C. The anti-gene strategy: Control of gene expression by triplex-forming-oligonucleotides. Anti-Cancer Drug Des. 1991, 6, 569-584.

2. Wagner, R.W. Gene inhibition using antisense oligodeoxynucleotides. Nature 1994, 372, 333-335.

3. Opalinska, J.B.; Gewirtz, A.M. Nucleic-acid therapeutics: Basic principles and recent applications. Nat. Rev. Drug. Discov. 2002, 1, 503-514.

4. Castanotto, D.; Stein, C.A. Antisense oligonucleotides in cancer. Curr. Opin. Oncol. 2014, 26, 584-589.

5. Dean, N.M.; Bennett, C.F. Antisense oligonucleotide-based therapeutics for cancer. Oncogene 2003, 22, 9087-9096.

6. Yang, W.Q.; Zhang, Y. RNAi-mediated gene silencing in cancer therapy. Expert Opin. Biol. Ther. 2012, 12, 1495-1504. 
7. Gao, S.; Yang, C.; Jiang, S.; Xu, X.-N.; Lu, X.; He, Y.-W.; Cheung, A.; Wang, H. Applications of RNA interference high-throughput screening technology in cancer biology and virology. Protein Cell 2014, 5, 805-815.

8. Sun, H.; Zhu, X.; Lu, P.Y.; Rosato, R.R.; Tan, W.; Zu, Y. Oligonucleotide aptamers: New tools for targeted cancer therapy. Mol. Ther. Nucleic Acids 2014, 3, e182.

9. Jiang, K. Biotech Comes to Its "Antisenses" after Hard-Won Drug Approval. Available online: http://blogs.nature.com/spoonful/2013/02/biotech-comes-to-its-antisenses-after-hard-won-drugapproval.html (Archived by WebCite ${ }^{\circledR}$ at http://www.webcitation.org/6WNb4M1rP) (accessed on 6 January 2015).

10. Lu, Q.L.; Cirak, S.; Partridge, T. What Can We Learn From Clinical Trials of Exon Skipping for DMD? Mol. Ther. Nucl. Acids 2014, 3, e152.

11. Soutschek, J.; Akinc, A.; Bramlage, B.; Charisse, K.; Constien, R.; Donoghue, M.; Elbashir, S.; Geick, A.; Hadwiger, P.; Harborth, J.; et al. Therapeutic silencing of an endogenous gene by systemic administration of modified siRNAs. Nature 2004, 432, 173-178.

12. De Fougerolles, A.; Vornlocher, H.P.; Maraganore, J.; Lieberman, J. Interfering with disease: A progress report on siRNA-based therapeutics. Nat. Rev. Drug. Discov. 2007, 6, 443-453.

13. Herdewijn, P. Heterocyclic modifications of oligonucleotides and antisense technology. Antisense Nucl. Acid. Drug Dev. 2000, 10, 297-310.

14. Herdewijn, P. Conformationally restricted carbohydrate-modified nucleic acids and antisense technology. Biochim. Biophys. Acta 1999, 1489, 167-179.

15. Manoharan, M. RNA interference and chemically modified small interfering RNAs. Curr. Opin. Chem. Biol. 2004, 8, 570-579.

16. Van Aerschot, A.; Verheggen, I.; Hendrix, C.; Herdewijn, P. 1,5-Anhydrohexitol nucleic acids, a new promising antisense construct. Angew. Chem. Int. Ed. Engl. 1995, 34, 1338-1339.

17. Hendrix, C.; Rosemeyer, H.; Verheggen, I.; Seela, F.; van Aerschot, A.; Herdewijn, P. 1',5'-Anhydrohexitol oligonucleotides: Synthesis, base pairing and recognition by regular oligodeoxyribonucleotides and oligoribonucleotides. Chem. Eur. J. 1997, 3, 110-120.

18. Allart, B.; Khan, K.; Rosemeyer, H.; Schepers, G.; Hendrix, C.; Rothenbacher, K.; Seela, F.; Van Aerschot, A.; Herdewijn, P. D-Altritol nucleic acids (ANA): Hybridisation properties, stability, and initial structural analysis. Chem. Eur. J. 1999, 5, 2424-2431.

19. Wang, J.; Verbeure, B.; Luyten, I.; Lescrinier, E.; Froeyen, M.; Hendrix, C.; Rosemeyer, H.; Seela, F.; van Aerschot, A.; Herdewijn, P. Cyclohexene nucleic acids (CeNA): Serum stable oligonucleotides that activate RNase $\mathrm{H}$ and increase duplex stability with complementary RNA. J. Am. Chem. Soc. 2000, 122, 8595-8602.

20. Singh, S.K.; Nielsen, P.; Koshkin, A.A.; Wengel, J. LNA (locked nucleic acids): Synthesis and high-affinity nucleic acid recognition. Chem. Commun. 1998, 455-456.

21. Veedu, R.N.; Wengel, J. Locked nucleic acids: Promising nucleic acid analogs for therapeutic applications. Chem. Biodivers. 2010, 7, 536-542.

22. Fisher, M.; Abramov, M.; van Aerschot, A.; Xu, D.; Juliano, R.L.; Herdewijn, P. Inhibition of MDR1 expression with altritol-modified siRNAs. Nucl. Acids Res. 2007, 35, 1064-1074.

23. Chatelain, G.; Schepers, G.; Rozenski, J.; van Aerschot, A. Hybridization potential of oligonucleotides comprising 3'-O-methylated altritol nucleosides. Mol. Divers. 2012, 16, 825-837. 
24. Richtmyer, N.K.; Hudson, C.S. Crystalline $\alpha$-methyl-D-altroside and some new derivatives of D-altrose1. J. Am. Chem. Soc. 1941, 63, 1727-1731.

25. Teste, K.; Colombeau, L.; Hadj-Bouazza, A.; Lucas, R.; Zerrouki, R.; Krausz, P.; Champavier, Y. Solvent-controlled regioselective protection of 5'-O-protected thymidine. Carbohydr. Res. 2008, 343, 1490-1495.

26. Lucas, R.; Teste, K.; Zerrouki, R.; Champavier, Y.; Guilloton, M. Chelation-controlled regioselective alkylation of pyrimidine 2'-deoxynucleosides. Carbohydr. Res. 2010, 345, 199-207.

27. Divakar, K.J.; Reese, C.B. 4-(1,2,4-Triazol-1-yl) and 4-(3-nitro-1,2,4-triazol-1-yl)-1-(beta-D-2,3,5tri-O-acetylarabinofuranosyl)pyrimidin-2(1H)-ones - Valuable intermediates in the synthesis of derivatives of 1-(beta-D-arabinofuranosyl)cytosine (Ara-C). J. Chem. Soc. Perk. Trans. 1 1982, 1171-1176.

28. Pulido, D.; Sánchez, A.; Robles, J.; Pedroso, E.; Grandas, A. Guanine-containing DNA minor-groove binders. Eur. J. Org. Chem. 2009, 2009, 1398-1406.

29. Jenny, T.F.; Schneider, K.C.; Benner, S.A. N-2-Isobutyrl-O-6-[2-(para-nitrophenyl)ethyl]guanine-A new building block for the efficient synthesis of carbocyclic guanosine analogs. Nucleos. Nucleot. 1992, 11, 1257-1261.

30. Mcbride, L.J.; Kierzek, R.; Beaucage, S.L.; Caruthers, M.H. Amidine protecting groups for oligonucleotide synthesis 16. J. Am. Chem. Soc. 1986, 108, 2040-2048.

31. Vu, H.; Mccollum, C.; Jacobson, K.; Theisen, P.; Vinayak, R.; Spiess, E.; Andrus, A. Fast Oligonucleotide deprotection phosphoramidite chemistry for DNA-synthesis. Tetrahedron Lett. 1990, 31, 7269-7272.

32. Theisen, P.; McCollum, C.; Andrus, A. N-6-Dialkylformamidine-2'-deoxyadenosine phosphoramidites in oligodeoxynucleotide synthesis - Rapid deprotection of oligodeoxynucleotides. Nucleos. Nucleot. 1993, 12, 1033-1046.

33. D’Alonzo, D.; van Aerschot, A.; Guaragna, A.; Palumbo, G.; Schepers, G.; Capone, S.; Rozenski, J.; Herdewijn, P. Synthesis and base pairing properties of 1',5'-anhydro-L-hexitol nucleic acids (L-HNA). Chem. Eur. J. 2009, 15, 10121-10131.

34. Van Aerschot, A.; Meldgaard, M.; Schepers, G.; Volders, F.; Rozenski, J.; Busson, R.; Herdewijn, P. Improved hybridisation potential of oligonucleotides comprising $O$-methylated anhydrohexitol nucleoside congeners. Nucl. Acids Res. 2001, 29, 4187-4194.

35. Vandermeeren, M.; Preveral, S.; Janssens, S.; Geysen, J.; Saison-Behmoaras, E.; Van Aerschot, A.; Herdewijn, P. Biological activity of hexitol nucleic acids targeted at Ha-ras and intracellular adhesion molecule-1 mRNA. Biochem. Pharmacol. 2000, 59, 655-663.

36. Fisher, M.; Abramov, M.; Van Aerschot, A.; Rozenski, J.; Dixit, V.; Juliano, R.L.; Herdewijn, P. Biological effects of hexitol and altritol-modified siRNAs targeting B-Raf. Eur. J. Pharmacol. 2009, 606, 38-44.

37. Pinheiro, V.B.; Taylor, A.I.; Cozens, C.; Abramov, M.; Renders, M.; Zhang, S.; Chaput, J.C.; Wengel, J.; Peak-Chew, S.Y.; McLaughlin, S.H.; et al. Synthetic genetic polymers capable of heredity and evolution. Science 2012, 336, 341-344.

38. Taylor, A.I.; Pinheiro, V.B.; Smola, M.J.; Morgunov, A.S.; Peak-Chew, S.; Cozens, C.; Weeks, K.M.; Herdewijn, P.; Holliger, P. Catalysts from synthetic genetic polymers. Nature 2015, 518, 427-430. 
39. Mooers, B.H.; Singh, A. The crystal structure of an oligo(U):pre-mRNA duplex from a trypanosome RNA editing substrate. RNA 2011, 17, 1870-1883.

40. Salomon-Ferrer, R.; Case, D.A.; Walker, R.C. An overview of the Amber biomolecular simulation package. Wires Comput. Mol. Sci. 2013, 3, 198-210.

41. Pettersen, E.F.; Goddard, T.D.; Huang, C.C.; Couch, G.S.; Greenblatt, D.M.; Meng, E.C.; Ferrin, T.E. UCSF Chimera-A visualization system for exploratory research and analysis. J. Comput. Chem. 2004, 25, 1605-1612.

Sample Availability: Only small amounts of the different amidites are still available from the authors.

(C) 2015 by the authors; licensee MDPI, Basel, Switzerland. This article is an open access article distributed under the terms and conditions of the Creative Commons Attribution license (http://creativecommons.org/licenses/by/4.0/). 